\title{
Geochemical characterisation of the Neoarchaean newer dolerite dykes of the Bahalda region, Singhbhum craton, Odisha, India: Implication for petrogenesis
}

\author{
Piyali Dasgupta*, Arijit Ray and Tushar Mouli Chakraborti \\ Department of Geology, Presidency University, 86/1 College Street, Kolkata 700 073, West Bengal, India. \\ *Corresponding author. e-mail: piysen@yahoo.co.in
}

MS received 1 November 2018; revised 8 May 2019; accepted 10 May 2019

The mafic dyke swarm, newer dolerite dykes (NDDs) intrudes the Archaean Singbhum granite of the Singhbhum craton, eastern India. The present investigation focuses on the petrography and geochemistry of 19 NNE-SSW to NE-SW trending NDDs in two sectors in the northern and south-western part of Bahalda town, Odisha, Singhbhum. Chondrite normalised rare earth element (REE) patterns show light REE (LREE) enrichment among majority of the 13 dykes while the remaining six dykes show a flat REE pattern. Critical analyses of some important trace element ratios like Ba/La, La/Sm, Nb/Y, Ba/Y, $\mathrm{Sm} / \mathrm{La}, \mathrm{Th} / \mathrm{La}, \mathrm{La} / \mathrm{Sm}, \mathrm{Nb} / \mathrm{Zr}$, Th/Zr, Hf/Sm, Ta/La and Gd/Yb indicate that the dolerite dykes originated from a heterogeneous spinel peridotite mantle source which was modified by fluids and melts in an arc/back arc setting. REE modelling of these dolerite dykes were attempted on LREE-enriched representative of NDD which shows that these dykes might have been generated by 5-25\% partial melting of a modified spinel peridotite source which subsequently suffered around $30 \%$ fractional crystallisation of olivine, orthopyroxene and clinopyroxene. The reported age of $\sim 2.75-2.8 \mathrm{Ma}$ seems to be applicable for these dykes and this magmatism appears to be contemporaneous with major scale anorogenic granitic activity in the Singhbhum craton marking a major event of magmatic activity in eastern India.

Keywords. Newer dolerite; Singhbhum granite; clouded plagioclase; back arc; partial melting.

\section{Introduction}

Mafic dyke swarms provide the most complete record (in the face of erosion, deformation, etc.) of short-lived, mantle-generated magmatic events through time and space. The emplacement of mafic dyke swarms is an important event throughout geological time and the event often acts as an important time marker in geological terrain (Weaver and Tarney 1981; Cadman et al. 1993; Wang et al. 2004; Halls 2008; Shellnutt and MacRae 2012). Collectively, the record of mafic dyke swarms provides information on 'the pulse of Published online: 03 August 2019 the Earth' - that is the rhythm of mantle melting events through time from minor rift-related events to the largest known igneous events on the planet, large igneous provinces extruding millions of $\mathrm{km}^{3}$ of basaltic melt over short intervals of time (<1 myr) (Coffin and Eldholm 1994; Ernst 2014). Precambrian mafic dyke swarms tend to be more voluminous in terms of the number, width and length of dykes compared to their Phanerozoic counterparts. Many of the shield regions all over the world records intrusions of Precambrian dyke swarms which provide important clues in understanding the Proterozoic tectonics, magmatism, 
crustal growth and specially continental reconstruction (Bleeker and Ernst 2006; Srivastava et al. 2010; Ernst et al. 2013; Evans 2013; Pisarevsky et al. 2013; Ernst 2014). In the Archaean Singhbhum craton, mafic dyke swarms popularly known as the newer dolerite dykes (NDDs) are found to have intruded the thick crust of the Archaean Singbhum granite (Dunn 1929; Jones 1934; Krishnan 1936; Dunn and Dey 1942; Saha 1949, 1952, 1994; Saha et al. 1973; Mallik and Sarkar 1994; Mahadevan 2002; Bose 2008; Maity et al. 2008; Kumar et al. 2017; Srivastava et al. 2018; Samal et al. 2019). The reticulate dyke swarm occurs in two major trends, NW-SE and NE-SW in the Singbhum craton (Dunn 1929; Dunn and Dey 1942; Saha et al. 1973; Bose 2008; Sengupta and Ray 2012; Sengupta et al. 2014). Mandal et al. (2006) studied the size and orientation pattern (NW-SE and NE-SW) of thousands of NDDs and interpreted that these types of complex size-distribution result from the combined effects of nucleation, propagation and coalescence of fractures. According to Dunn and Dey (1942), the petrogenetic evolution of NDDs initiated with mafic magma underplating beneath the granitic crust followed by a stage of isostatic sagging, upliftment and subsequent dyke emplacement along a reactivated fracture system. Bose (2000) suggested that the parent magma of these NDDs were derived from both depleted and fertile sources in the subcontinental mantle or in the depleted oceanic lithosphere during an extension event of basin formation due to mantle upwelling. Later studies on NDDs from the northern part of the Singhbhum craton reported the origin of these dykes in a back arc setting (Bose 2008; Mir et al. 2010, 2011; Sengupta et al. 2014).

Earlier studies on geochronology indicate that the $\mathrm{K}-\mathrm{Ar}$ whole rock age of these dyke swarms vary from 2144 to 950 Ma (Sarkar et al. 1969; Sarkar and Saha 1977; Mallik and Sarkar 1994). An older Rb-Sr whole rock isochron age of $2613 \pm 177$ Ma (Roy et al. 2004) was also reported for a NNE-SSW trending ultramafic dyke from the northern part of the craton. Shankar et al. (2014) reported $\mathrm{Pb}-\mathrm{Pb}$ baddeleyite ages of $1765-1766 \mathrm{Ma}$ of two dykes from the south of Keonjhar, Odisha. Kumar et al. (2017) have reported $\mathrm{Pb}-\mathrm{Pb}$ baddeleyite ages of eight NNE-SSW dyke samples across the entire terrain of the dyke swarm, out of which six show ages of $2762.4 \pm 2.0 \mathrm{Ma}$ and the other two yielded ages of $2800.2 \pm 0.7$ and $2752.0 \pm 0.9 \mathrm{Ma}$, respectively. Recently, Srivastava et al. (2018) divided these NDD into the seven major swarms, ranging in age from $\sim 2.80 \mathrm{Ga}$ (Neoarchaean) to $\sim 1.76 \mathrm{Ga}$ (Palaeoproterozoic).

In the present work, we studied petrology and geochemistry of NNE-SSW to NE-SW trending NDDs from the northern part of the Singhbhum craton, in two sectors which are located in the northern and south-western parts of Bahalda village, Odisha (figure 1). Out of the seven dyke swarms reported by Srivastava et al. (2018), the dykes analysed in the present study fall within the NNE-SSW to NE-SW trending Ghatgaon dyke swarm of $\sim 2.75-2.76 \mathrm{Ga}$ age. In the present research, an attempt has been made to understand the petrogenetic issue of the NDDs of the Bahalda region, Odisha, including the nature of mantle source, contamination process involved in the mantle source prior to melting, partial melting process, degree of crustal contamination if any through a study of petrology-geochemistry and rare earth element (REE) modelling.

\section{Geological background}

The Singhbhum Odisha craton in the eastern Indian shield represents roughly a triangular area consisting of the arcuate Singhbhum shear zone in the north and the Sukinda thrust in the south (Saha 1994). The Singhbhum granite (phase I, II, III) of 3.3-2.8 Ga (Saha 1994; Bose 2008) forms a large part of this craton. The major rock formations of the craton include supracrustals of the older metamorphic group (OMG), older metamorphic tonalite gneisses, granitoids and tonalities of the Singhbhum granite batholith and the greenschist facies sediments and banded iron formations interlayered with mafic and felsic volcanic rocks of the iron ore group (IOG). The oldest rock group in this region is the OMG of 3.3 Ga (Saha 1994), consisting of meta-sedimentary and meta-igneous rocks found as large enclaves within the Singhbhum granite (figure 1). It comprises pelitic schists, quartz-magnetite-cumingtonite schists, quartzites, banded calc-gneiss and para and ortho amphibolites reflecting the first cycle of mafic volcanism, plutonism and sediment deposition in the Singhbhum craton (Singh et al. 2017). The IOG greenstone belt successions flank the perimeter of the pluton (figure 1) showing low-grade volcanosedimentary successions consisting of banded iron formation, mafic and felsic volcanic rocks, chert, shale and carbonate (Acharyya 1993; Saha 


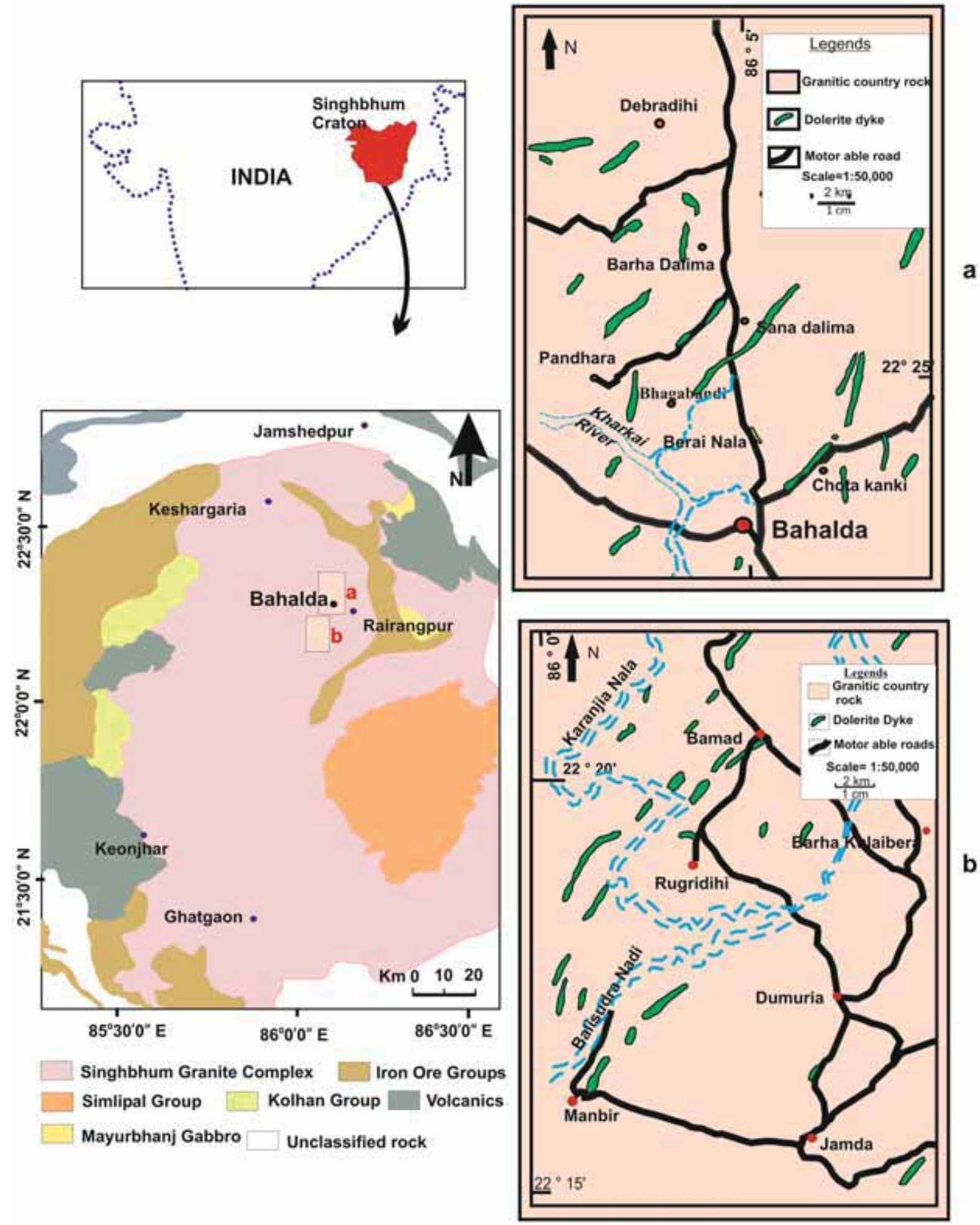

Figure 1. Geological map of the Singhbhum region showing the study area along with different rock types of the adjoining areas (modified after Saha 1994; Kumar et al. 2017; Srivastava et al. 2018; Samal et al. 2019) along with a map of the study area consisting of two sectors marked as (a) and (b) showing the occurrences of NDD.

1994; Mukhopadhyay 2001; Nelson et al. 2014; Upadhyaya et al. 2014). The volcano-sedimentary sequences of IOG were deposited in the Gurumahisani-Badampahar basin in the east,

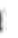

b

Noamundi-Jamda-Koira basin in the west and Tomka-Daitari basin in the south of the Singhbhum craton. These three IOG basins comprise overall similar lithostratigraphic successions 

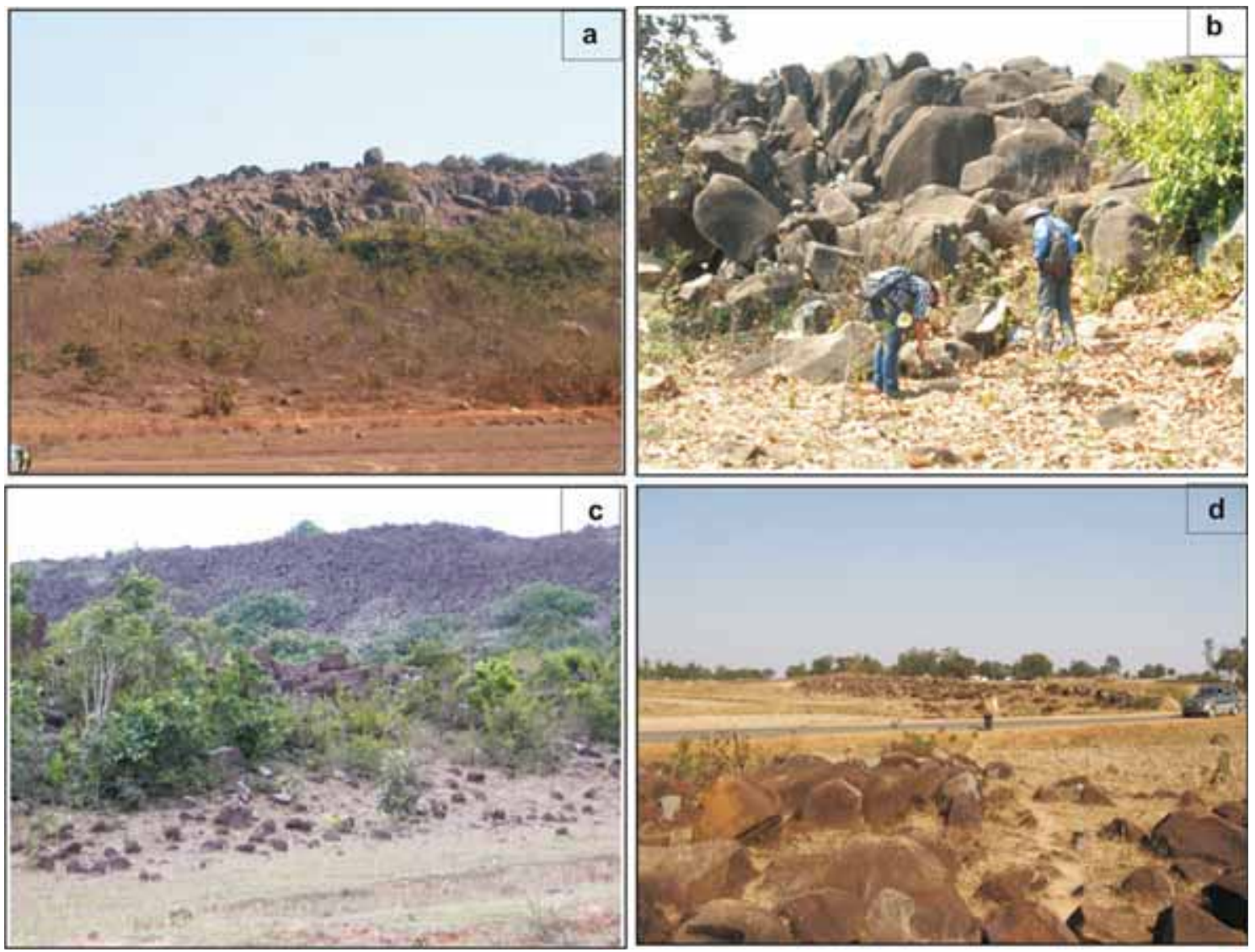

Figure 2. Field photograph of NDD occurring as a low height hill (a); small hillock (b); long serrated ridge (c); and stony waste (d).

marked by basal sandstones and conglomerates overlain by ferruginous shales, cherts, tuffs, tuffaceous shales, ultramafic-mafic-felsic volcanic rocks and banded iron formations (Saha 1994; Misra 2006; Mukhopadhyay et al. 2012; Nelson et al. 2014; Manikyamba et al. 2015). Mafic rocks occur profusely within the craton as represented by the orthoamphibolite of the OMG, basalts of the IOG, basic rocks of the Dalma, Dhanjori, Jagannathpur group (Saha 1994), dolerite dykes of Chaibasa formation of the Singhbhum group (Bose et al. 1989) and NDDs within the Singhbhum granite (Dunn 1929; Krishnan 1936; Dunn and Dey 1942; Saha 1994; Mahadevan 2002; Bose 2008; Mir et al. 2010; Sengupta and Ray 2012; Sengupta et al. 2014). NDDs are confined only within the Singhbhum granite and the term 'newer dolerite' was given by Dunn and Dey (1942) to distinguish these dykes from other metabasic bodies of the Singhbhum craton.

The area of the present study covers two sectors, (a) and (b), in the northern part of the Singhbhum craton. Sector (a) covers an area (between lat. $22^{\circ} 22^{\prime}-22^{\circ} 23^{\prime}$ and long. $\left.86^{\circ} 2^{\prime}-86^{\circ} 7^{\prime} 30^{\prime \prime}\right)$ in the north of the town of Bahalda, while sector (b) (between lat. $22^{\circ} 15^{\prime}-22^{\circ} 22^{\prime}$ and long. $86^{\circ} 00^{\prime}-86^{\circ} 5^{\prime}$ ) is located in the south-western part of the same Bahalda village in the state of Odisha, eastern India (figure 1). The dolerite dykes outcrop as a series of linearly arranged low height hills, small hillocks (figure $2 \mathrm{a}$ and $\mathrm{b}$ ), as long serrated ridges (figure 2c) and also as stony wastes (figure 2d) within the Singhbhum granite dominantly showing NNE-SSW to NE-SW trends (figure 1).

\section{Analytical technique}

The mode of occurrences and composition of constituent minerals of NDDs were studied with the help of a NIKON research grade polarising microscope (Model LV-100N Pol) using thin sections of rocks. The mineral compositions were determined by using EPMA in the laboratory of the Geological Survey of India, Kolkata (CAMECA Sx 100 using $15 \mathrm{kV}$ voltage, $12 \mathrm{nA}$ current and a beam size of $1 \mu \mathrm{m})$. All natural standards were used for the analyses of $\mathrm{Ca}, \mathrm{Fe}, \mathrm{Si}, \mathrm{Al}$, $\mathrm{Na}, \mathrm{Mg}, \mathrm{Cr}, \mathrm{K}, \mathrm{Ni}$ and $\mathrm{P}$ elements. For the analyses of 
$\mathrm{Mn}$ and Ti, the synthetic mineral standards were used. Selected probe data of minerals are presented in tables 1 and 2. Rock samples were analysed to determine major element abundances from Wadia Institute of Himalayan Geology, Dehradun, India. Samples were carefully chosen avoiding weathered surfaces and reduced to powder form (200 mesh) with an agate mortar. Major elements were determined using the X-ray fluorescence (XRF) (SIEMENS SRS 3000) facility. Sample powders were converted into pellet form for introduction into the instrument. Analysis of major elements by XRF has over $98 \%$ accuracy. Major element data are shown in table 3. Trace elements including REE abundances of these 19 samples were determined by inductively coupled plasma mass spectrometry techniques using Perkin Elmer, Sciex ELAN DRC II system at National Geophysical Research Institute, Hyderabad, India. In the present investigation, the samples were prepared by open acid digestion method. In this method, $0.05 \mathrm{~g}$ of sample was taken in PTFE Teflon beakers. Each sample was moistened with few drops of ultrapure water. Then 10 $\mathrm{ml}$ of an acid mixture (containing 7:3:1 $\mathrm{HF}-\mathrm{HNO}_{3-}$ $\mathrm{HClO}_{4}$ ) was added to each sample. Samples were swirled until completely moist. The beakers were then covered with lids and kept overnight for digestion after adding $1 \mathrm{ml}$ of $5 \mu \mathrm{g} / \mathrm{ml} \mathrm{Rh}$ solution (to act as an internal standard). The following day, the beakers were heated on a hot plate at $\sim 200^{\circ} \mathrm{C}$ for about $1 \mathrm{~h}$, the lids were removed and the contents were evaporated to almost dryness until a crystalline paste was obtained. Then the remaining residues were dissolved using 10 $\mathrm{ml}$ of $1: 1 \mathrm{HNO}_{3}$ and kept on a hot plate for $10 \mathrm{~min}$ on gentle heat $\left(70^{\circ} \mathrm{C}\right)$ for dissolving all suspended particles. Finally, the volume was increased to $250 \mathrm{ml}$ with purified water (18 M $\Omega$ ) and stored in polyethylene bottles. Trace element and REE data are presented in table 3. International rock standards like BHVO-1 (major elements) and JB2 (trace and REE) were run along with the samples to check the precision and accuracy of the measurements (Govindaraju 1994). The analysed and certified values of BHVO-1 and JB2 are given in table 3.

\section{Petrography and mineralogy of dolerites}

Mafic rocks from the NDDs occur both as finegrained phyric and coarse-grained aphyric varieties. A thin section study reveals that rocks from all the variably trending dykes show more or less similar petrographical characters. They are essentially composed of clinopyroxene and plagioclase which occur both as phenocryst and groundmass as a porphyritic variety or form a mosaic showing an intergranular texture as a non-porphyritic variety. Clinopyroxenes occur as single prismatic grains and also as clusters (figure 3a). Compositionally, clinopyroxenes of dolerite dykes show a wide range of compositional variation $\left(\mathrm{Wo}_{41.5} \mathrm{En}_{44.7} \mathrm{Fs}_{13.8}\right.$ to $\left.\mathrm{Wo}_{7.7} \mathrm{En}_{39.6} \mathrm{Fs}_{52.3}\right)$ from augite, subcalcic augite, ferroaugite to pigeonite (figure $4 \mathrm{a}$, table 1 ). Some of the clinopyroxene grains are zoned where the rim is more iron-enriched than the core (table 1). In some dykes, clinopyroxenes are variably replaced by chlorite, tremolite and actinolitic amphibole (figure $3 \mathrm{~b}$ ). In some dykes, bastitised orthopyroxenes (figure 3c) were observed leaving small relicts of clinoenstatite at a few places (table 1). Fresh plagioclase grains are very rare and occur mostly as clouded grains showing a patchy appearance (figure 3d). Compositions of plagioclase grains are shown in figure 4(b). A wide variation of the composition from $\mathrm{An}_{95.9}$ to $\mathrm{An}_{49.7}$ (table 2) is observed in different parts of an unzoned clouded plagioclase grain. This variation is considered as the result of the unmixing of plagioclase of intermediate composition. During the metamorphism of basic rocks of high iron content, the entrance of Ferich solutions along the zones of unmixing of plagioclase precipitate submicroscopic grains of iron mineral (Poldervaart and Gilkey 1954; Sengupta et al. 2014). Except clouding, some plagioclases also show effects of alteration like saussuritisation and sericitisation. Plagioclase grains devoid of clouding are mostly albite with some andesine (figure $4 \mathrm{~b}$, table 2 ). The common accessory mineral in the rock is magnetite which is associated occasionally with ilmenite. Few biotite and sphene also occur as accessories. The presence of actinolitic amphibole, bastitised orthopyroxene and clouded plagioclase suggests hydrothermal alteration under low grade metamorphism (Sengupta and Ray 2012).

\section{Geochemistry}

For geochemical studies, 19 samples were selected from fresh portions of 19 large dolerite dykes of the present study. Petrographic studies revealed that these dolerite rocks have been affected by hydrothermal alteration. So to characterise the dolerite dykes of the present study, we used an abundance of relatively immobile trace elements (which remain unchanged during weathering and 


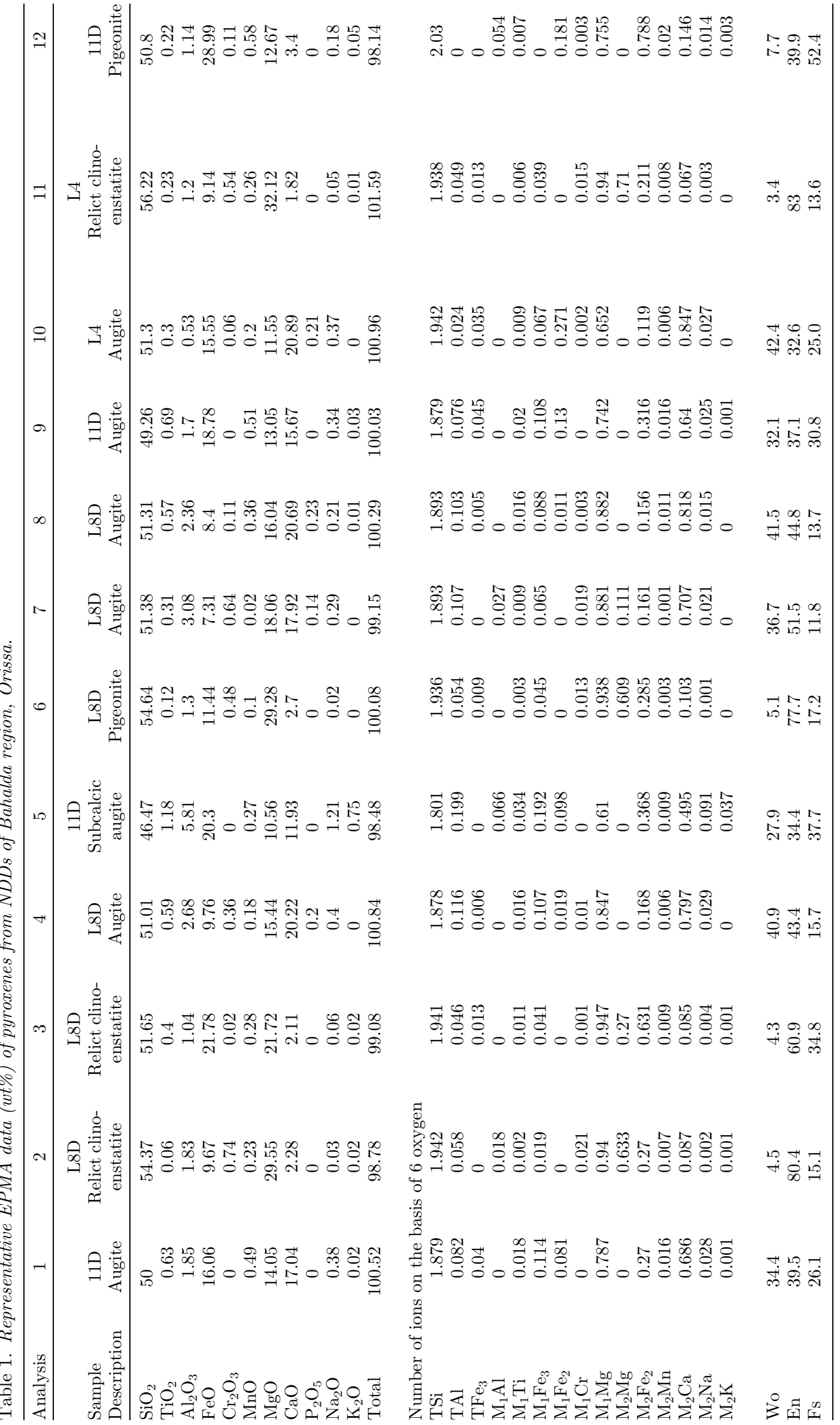




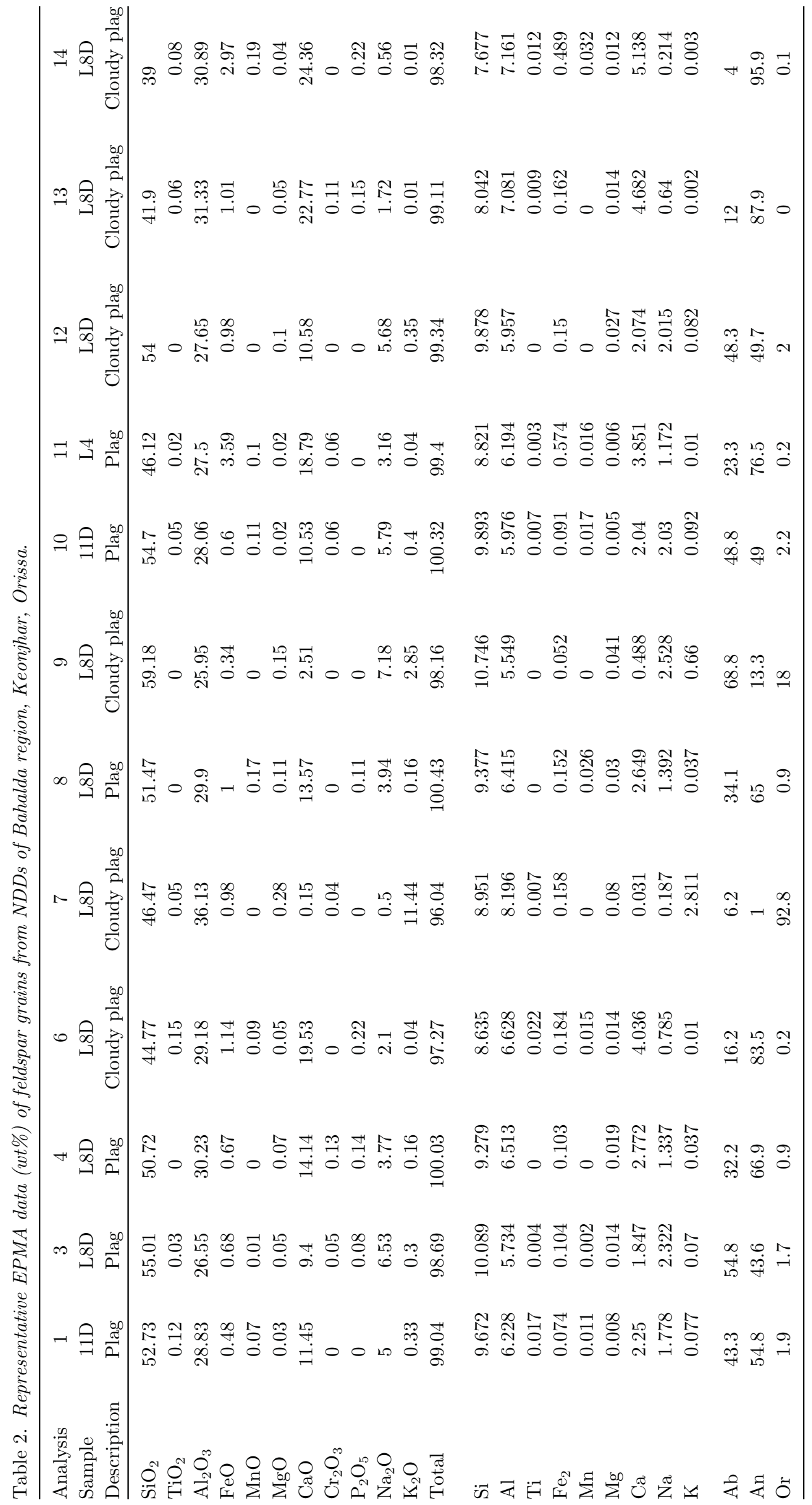




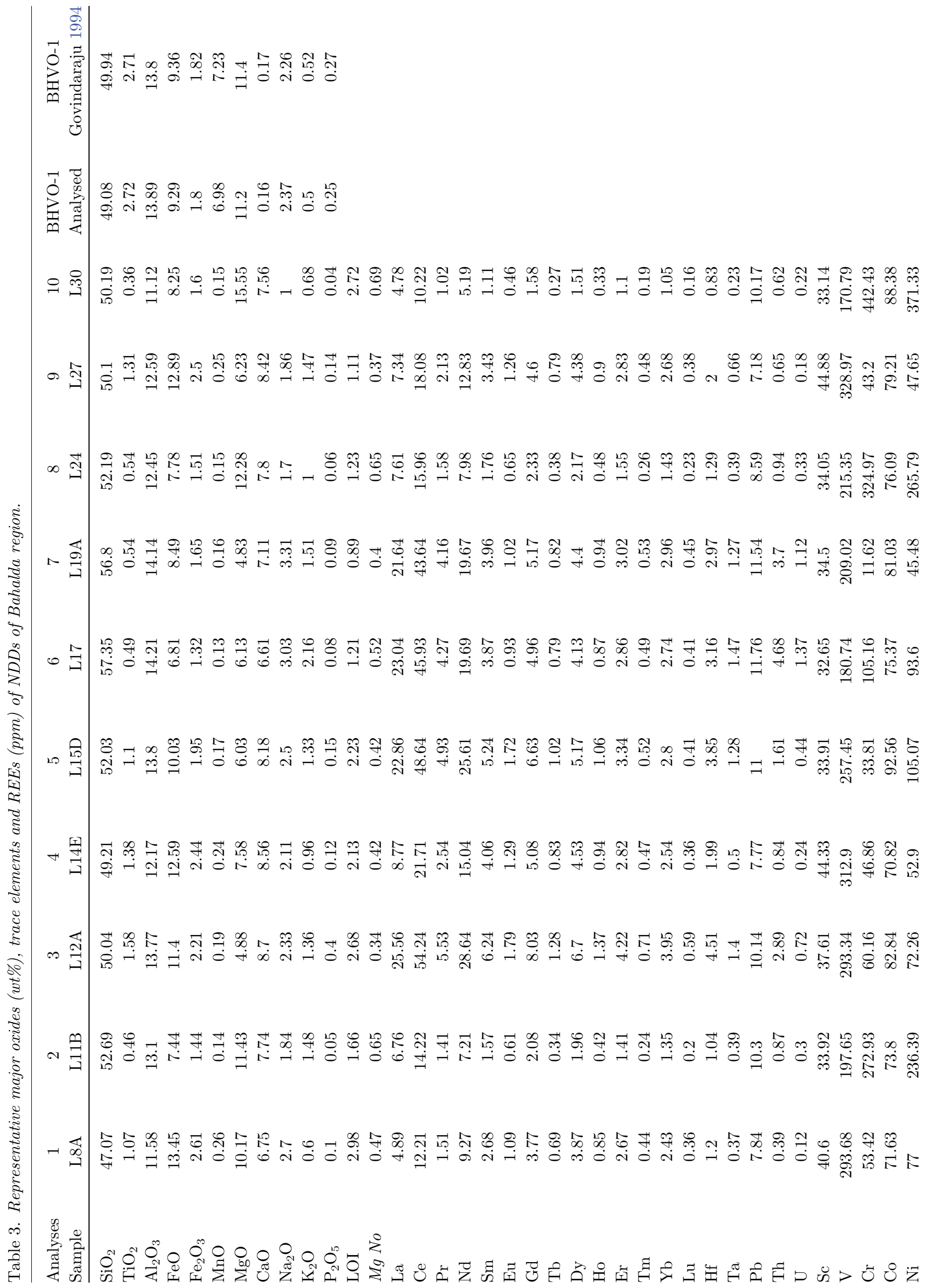




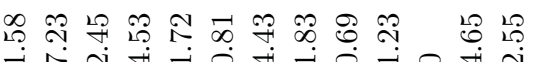

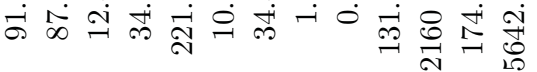

F⿻ి

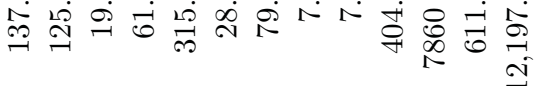

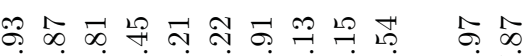
ภู่

눙

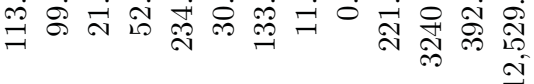

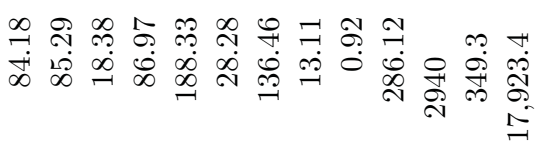

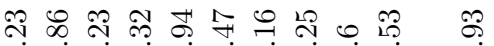

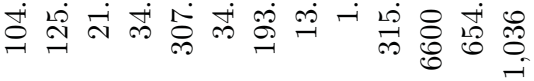

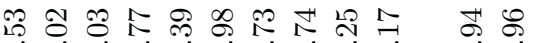
穵 ๙

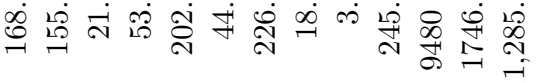
든 따의

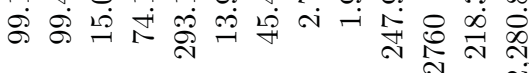

เ

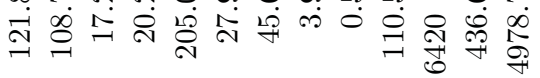

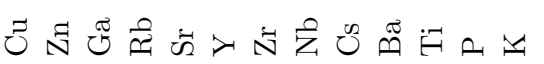

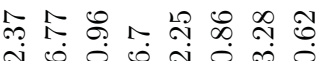

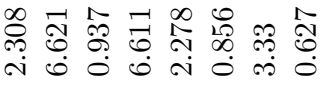

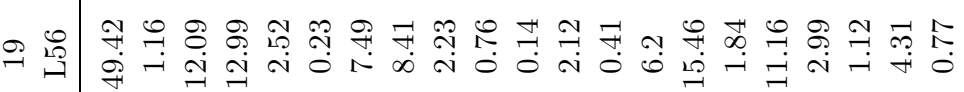

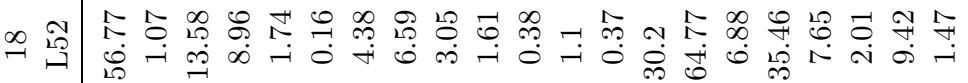

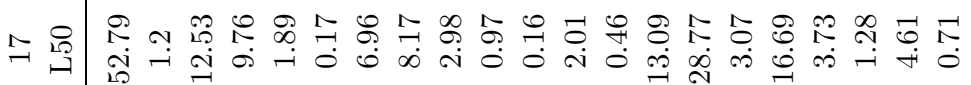

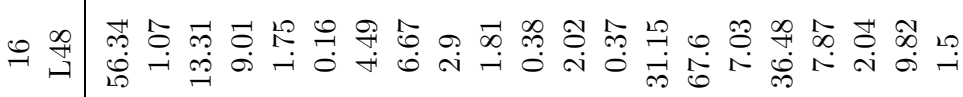

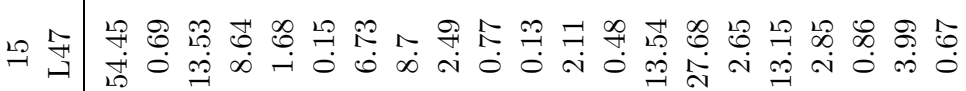

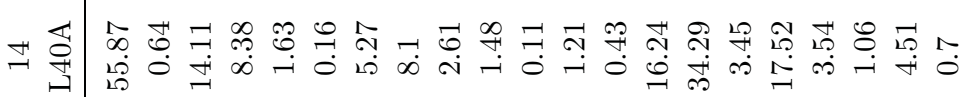

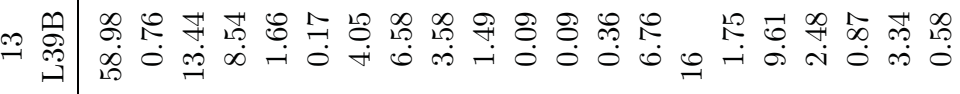

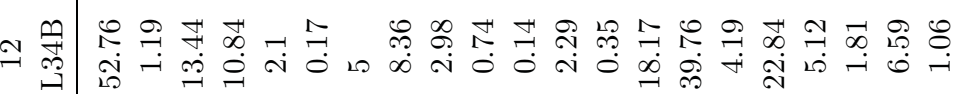

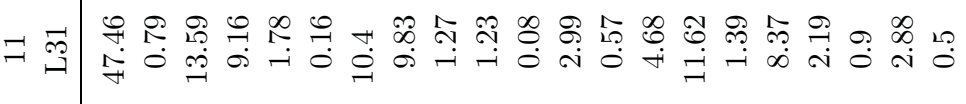

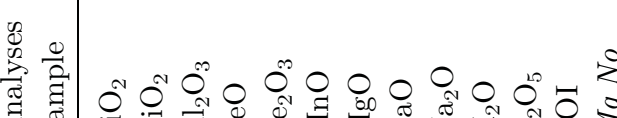




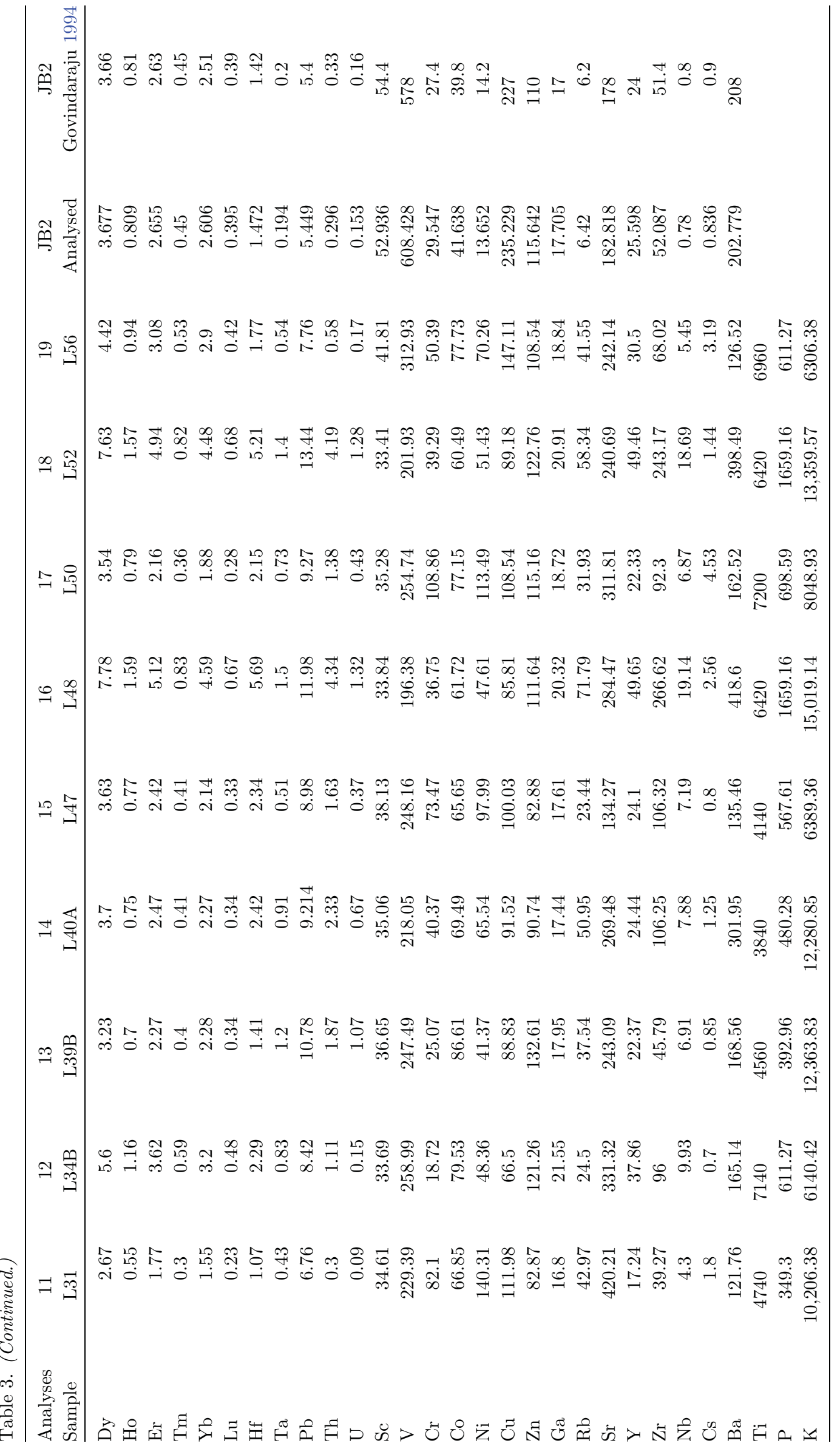



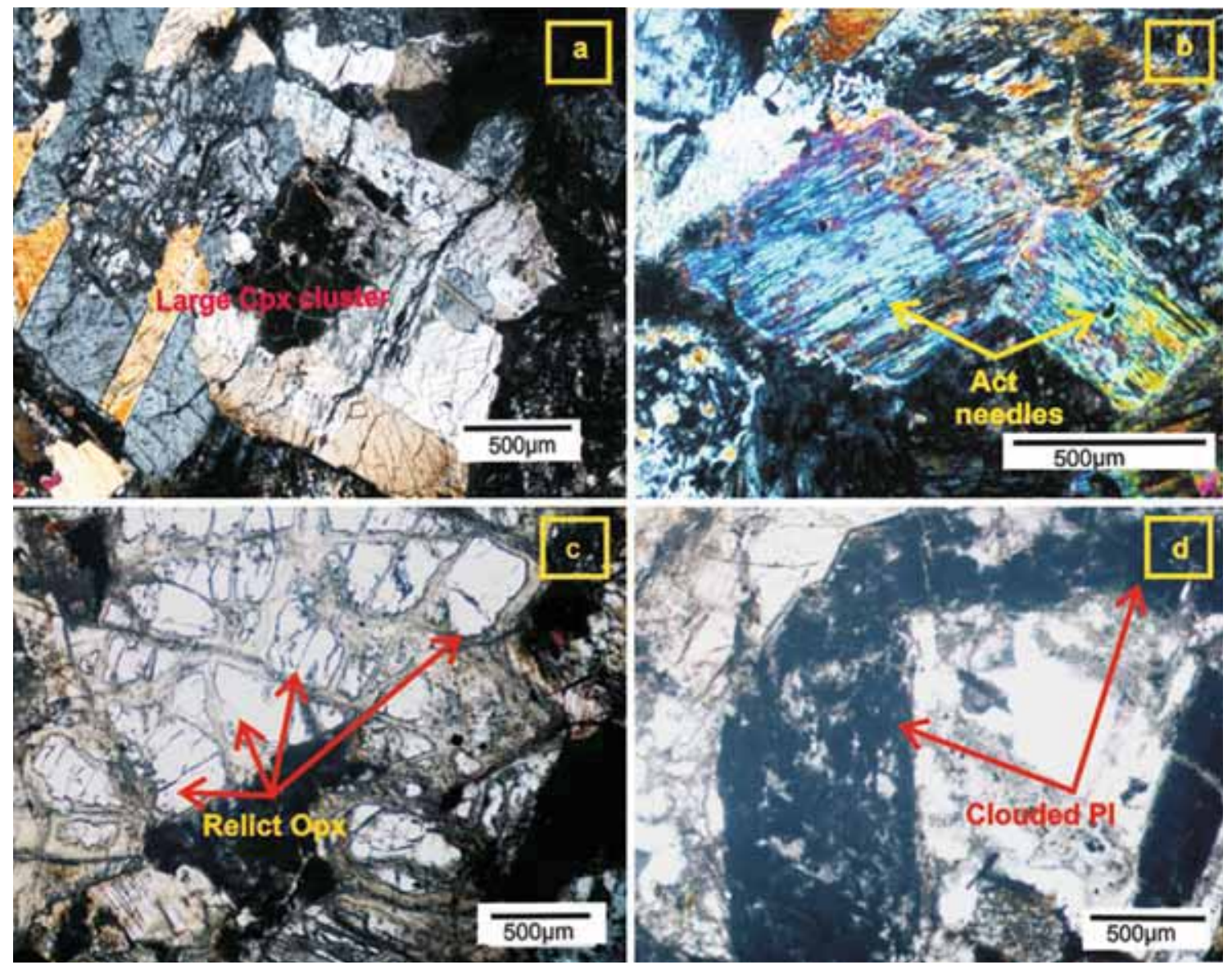

Figure 3. Photomicrographs of NDD of the study area: (a) clusters of clinopyroxene phenocrysts showing porphyritic/ glomeroporphyritic texture (crossed polars), (b) actinolite needles replacing clinopyroxene grains, crossed polars, (c) bastitised orthopyroxene grains with relict orthopyroxene and (d) clouded plagioclase grains in plane polarised light.

a

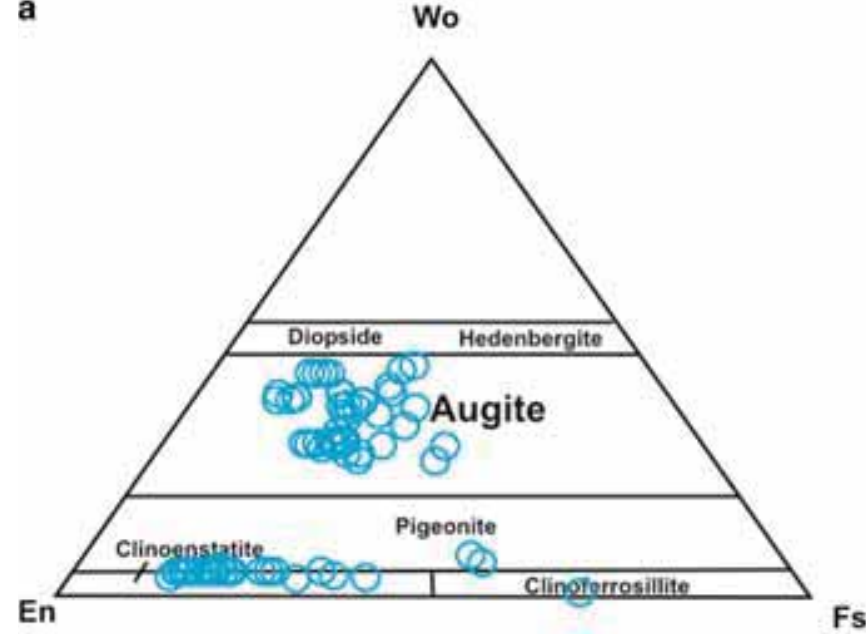

b

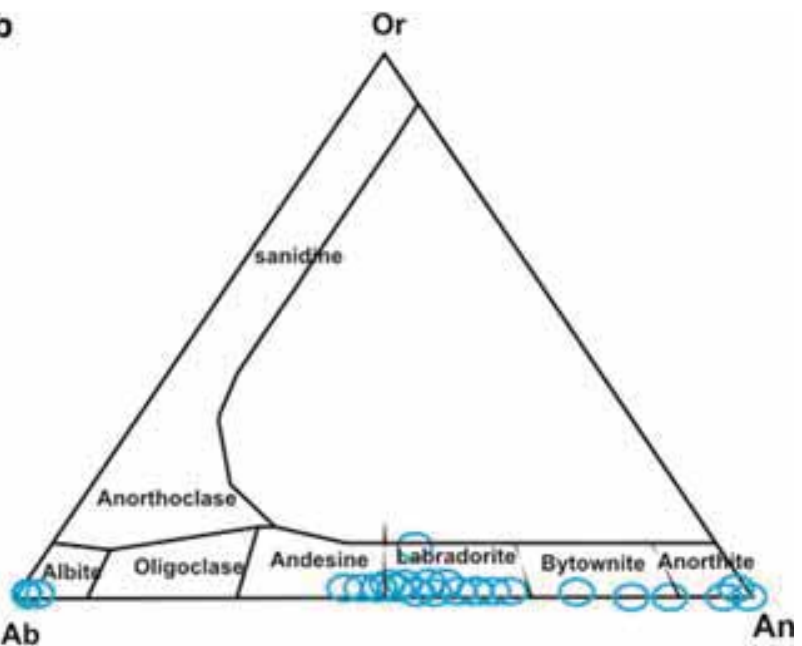

Figure 4. (a) Plots of pyroxene compositions of NDD in a Wo-En-Fs diagram. (b) Plots of plagioclase of NDD in a Or-Ab-An diagram. Respective pyroxene and plagioclase compositions are represented by hollow blue circles.

low grade metamorphism) to avoid problems of element mobility during metamorphism (Pearce 1996; Sengupta et al. 2014).
The chemical composition of NDD indicates that the rocks are silica saturated to oversaturated $\left(\mathrm{SiO}_{2}\right.$ ranges from $47 \%$ to $\left.59 \%\right)$ basic rocks with 


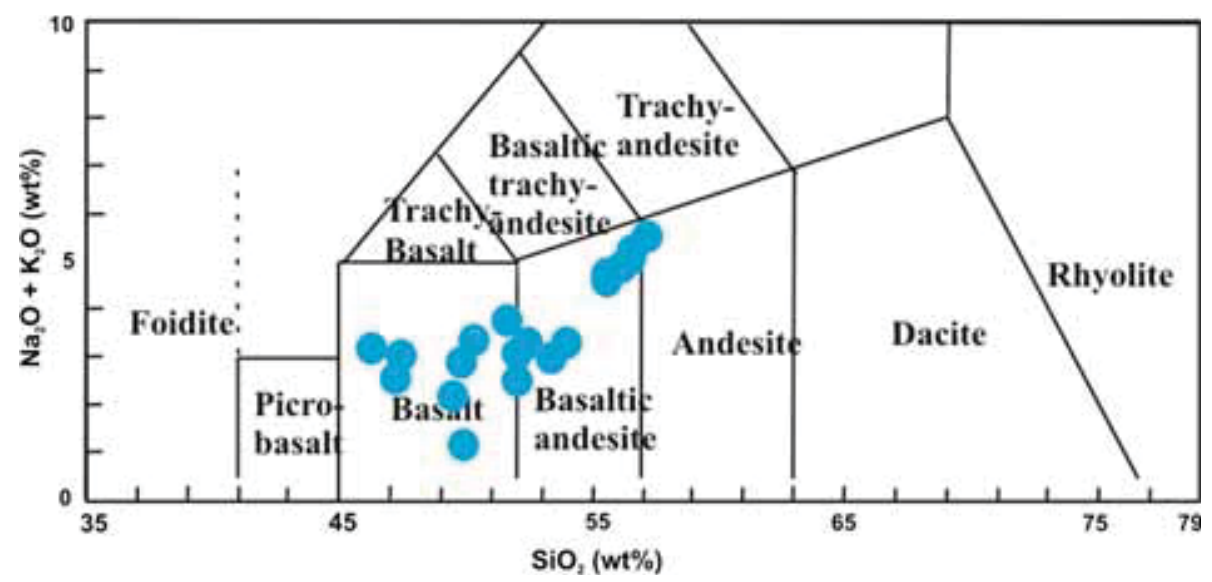

Figure 5. Plots of NDD in a TAS diagram (Le Bas 2000). NDD samples of the study area are indicated by blue-coloured filled circles.

varying Mg no. (36-69). Dolerites are basalt to basaltic andesite in composition as observed from their plots in the IUGS-recommended TAS diagram (figure 5). They also plot in the field of tholeiitic basalts in the AFM diagram (figure 6). Both major and trace element concentrations show wide variations (table 3). Few large ion lithophile elements (LILEs) such as Rb, Ba and Sr show pronounced variation (table 3 ). Th and $\mathrm{U}$ also show different abundance levels; some samples like L17, L48 and L52 show a high abundance level of Th and $\mathrm{U}$ in contrast to others like L8A, L14E, L27 and L56 which show a lower value. Elements like $\mathrm{Zr}, \mathrm{Nb}$ and $\mathrm{Y}$ show a wide variation with few samples like L12A, L48 and L52 showing relatively higher values of $\mathrm{Zr}, \mathrm{Nb}$ and $\mathrm{Y}$ (table 3).

To have a clear understanding of the nature of the chemical variation in different dykes, we used several binary plots with some important major and trace elements like $\mathrm{Zr}-\mathrm{Nb}, \mathrm{Ni}-\mathrm{MgO}, \mathrm{CaO} /$ $\mathrm{Al}_{2} \mathrm{O}_{3}$ vs. $\mathrm{MgO}, \mathrm{Al}_{2} \mathrm{O}_{3}-\mathrm{MgO}, \mathrm{Zr}-\mathrm{La}$ and $\mathrm{Zr}-\mathrm{Ba}$ as shown in figure $7(\mathrm{a}-\mathrm{f})$. In the $\mathrm{Zr}-\mathrm{Nb}$ plot (figure 7a), majority of the samples display a distinct linear trend with a positive correlationship between the elements, indicating the evolution from a common magma source by crystal fractionation. In the $\mathrm{MgO}-\mathrm{Ni}$ (figure $7 \mathrm{~b}$ ) and $\mathrm{CaO} /$ $\mathrm{Al}_{2} \mathrm{O}_{3}$ vs. $\mathrm{MgO}$ (figure $7 \mathrm{c}$ ) plot, majority of the samples display a positive linear trend between the parameters, indicating the fractionation of orthopyroxene and clinopyroxene, respectively, during magmatic evolution. A positive correlation between $\mathrm{Al}_{2} \mathrm{O}_{3}$ and $\mathrm{MgO}$ in figure $7(\mathrm{~d})$ indicates that the fractionation of the plagioclase has played an important role during petrogenesis. However, few samples in all these diagrams do not show

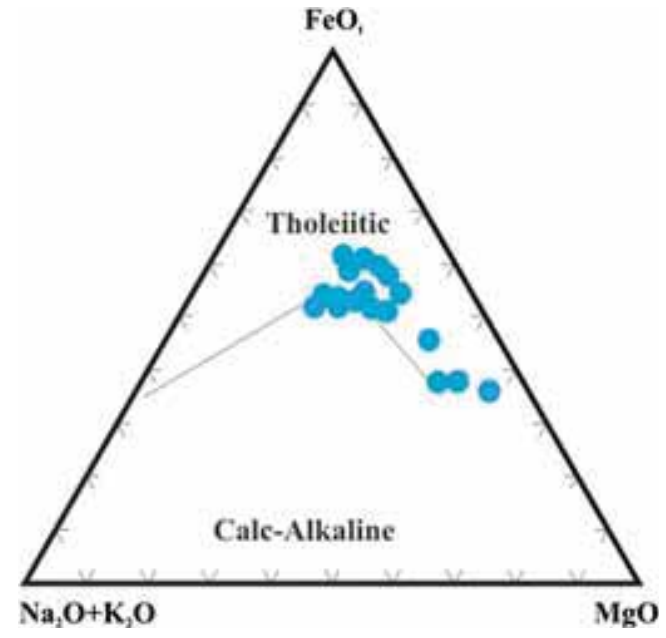

Figure 6. Plots of NDD of Bahalda in an AFM diagram (after Irvine and Baragar 1971). Symbols are the same as in figure 5 .

significant spread or do not fall along the major linear trend (figure $7 \mathrm{~b}$ and $\mathrm{c}$ ). Binary plots of Zr vs. La (figure 7e) and Zr vs. Ba (figure 7f) have been made to test the validity of the use of LILE and HFSE during petrogenetic interpretations. Both of these figures show distinct positive trends of variation which rules out the possibility of the modification of these elements during hydrothermal alteration specially $\mathrm{Ba}$ which is known to be a very mobile element. If these elements were modified by secondary processes, then the perfect positive variation trend would have been distorted.

In the chondrite-normalised REE plot (Sun and McDonough 1989) of 19 NDD (figure 8), the majority of 13 dykes (L11B, L12A, L15D, L17, L19A, L24, L30, L34B, L40A, L47, L48, L50, L52) 

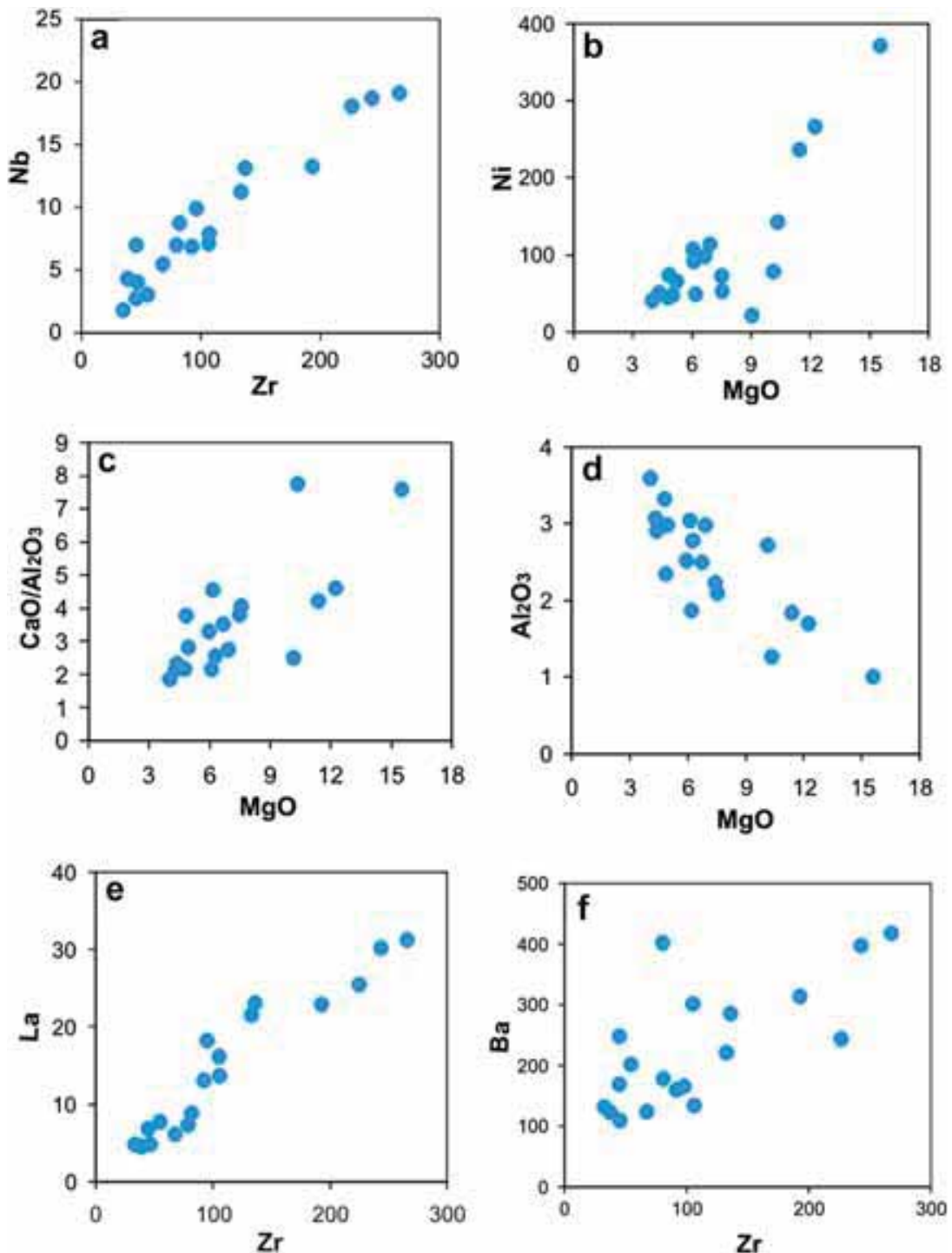

Figure 7. Binary plots of some important major and trace elements (in ppm) of NDD of the study area. Symbols are the same as in figure 5 .

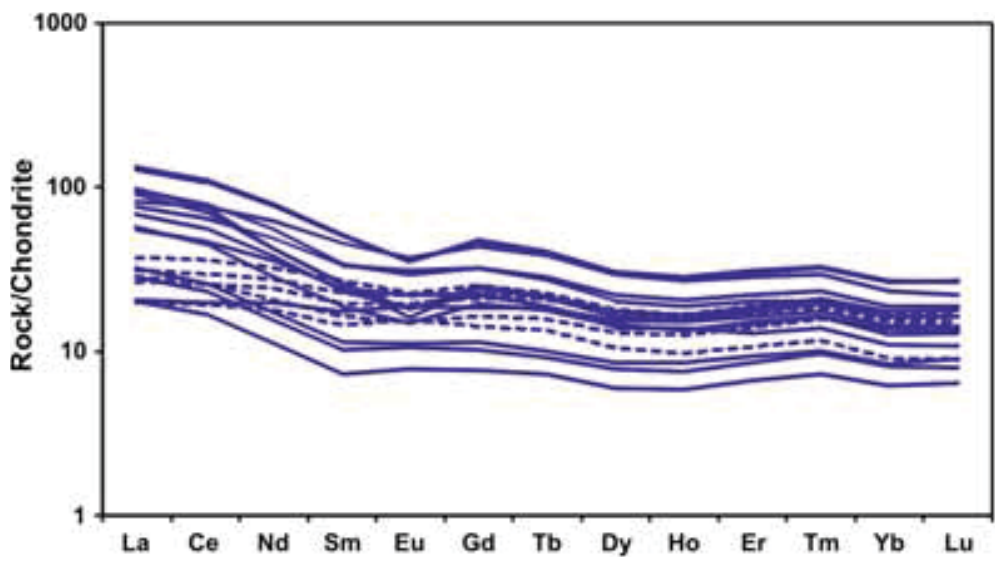

Figure 8. Chondrite normalised REE patterns (Sun and McDonough 1989) of the NDD with 13 dykes showing LREE enriched pattern (solid lines) and six dykes showing a nearly flat pattern (dotted lines). 


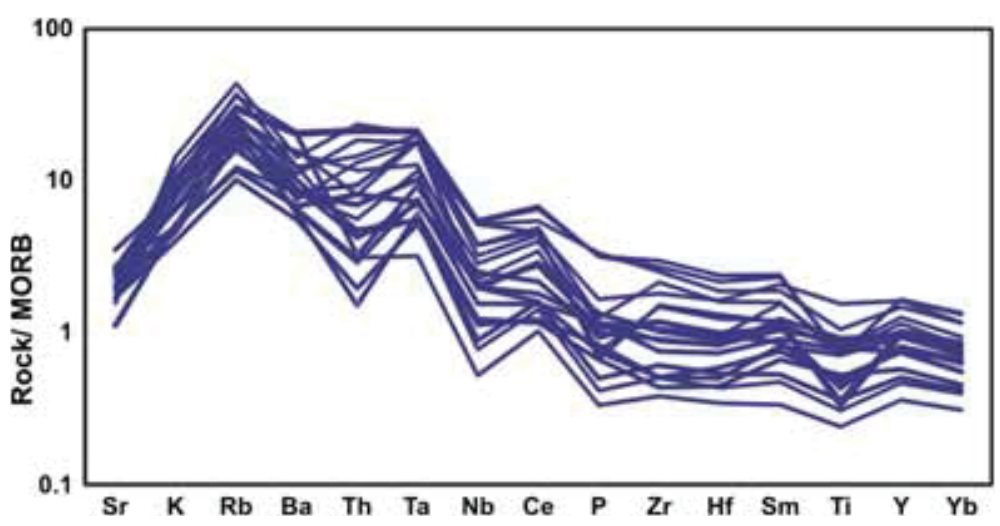

Figure 9. MORB normalised multi-element spider diagram (Pearce 1983) of the NDD showing positive anomalies at K, Ba and $\mathrm{Rb}$ and negative anomalies at $\mathrm{Nb}, \mathrm{P}$ and $\mathrm{Ti}$.

show an enrichment of light REE (LREE) over heavy REEs (HREEs) (with $(\mathrm{La} / \mathrm{Sm})_{N}$ ratio from 2.2 to 3.8 and $(\mathrm{Ce} / \mathrm{Yb})_{N}$ ratio $\left.2.9-4.8\right)$ while the other six dykes show a relatively flat pattern with a slight enrichment of the incompatible LREEs where the $(\mathrm{La} / \mathrm{Sm})_{N}$ ratio varies from 1.1 to 1.7 and the $(\mathrm{Ce} / \mathrm{Yb})_{N}$ ratio from 1.3 to 2.3. When plotted using a multi-element spidergram (Pearce 1983), the dykes show positive anomalies at K, Ba and $\mathrm{Rb}$ and negative anomalies at $\mathrm{Nb}, \mathrm{P}$ and $\mathrm{Ti}$ (figure 9). Th shows both negative and positive anomalies. Dolerites with enrichment of LILEs like $\mathrm{Ba}, \mathrm{Rb}, \mathrm{K}$ and Sr over high field-strength elements like $\mathrm{Nb}, \mathrm{Y}$ and $\mathrm{Ti}$, variable enrichment in LREEs (La, Ce, Pr) over HREEs and distinct negative anomaly at $\mathrm{Nb}, \mathrm{P}$ and $\mathrm{Ti}$ indicate their generation due to the melting of a chemically heterogeneous mantle source (Wilson 1989).

The diagrams $\mathrm{Nb}-\mathrm{Zr}-\mathrm{Y}$, Hf-Th-Nb (figure 10a and $b$ ) have been found to be useful for the identification of their chemical characteristics. These diagrams were prepared using chemical data of recent to phanerozoic igneous rocks. However, these diagrams have also been used by several researchers for the chemical characterisation of Precambrian magmatic rocks (Dostal et al. 1990; Volkert et al. 2015). Although it is not a very definite tool, it gives an idea about the chemical affinity of the igneous rocks in terms of their modern day analogue. In the $\mathrm{Nb} * 2-\mathrm{Zr} / 4-\mathrm{Y}$ diagram after Meschede (1986), most of the samples of the dolerite dykes of our study area fall in the volcanic arc basalt field (C and D) with few samples in the E-MORB field (B) (figure 10a). In the $\mathrm{Hf} / 3-\mathrm{Th}-\mathrm{Nb} / 16$ diagram (figure 10b) after Wood (1980), most of the samples fall in the field of the arc region with few plotted in the E-MORB field (figure 10b). Another diagram of $\mathrm{Ba} / \mathrm{La}$ vs. $\mathrm{Nb} / \mathrm{La}$ (figure 10c) was also found to be useful in this context. In this diagram, most of the dolerite samples fall along the trend of arc magmas (Regelous et al. 1997; Ewart et al. 1998; Escrig et al. 2009). Few samples fall just above the trend of E-MORBs (Peate et al. 2001; Escrig et al. 2009). Thus, it may be concluded from these three diagrams that the rocks of NDD have geochemical similarity with arc/back arc basalt.

\section{Petrogenesis}

\subsection{Crustal contamination}

It is essential to study the role of crustal contamination before discussing the nature of the mantle source and petrogenetic processes. The broad similarity in the immobile, incompatible element behaviour of the dolerite dykes suggests a negligible amount of crustal contamination during the emplacement of the en route crust. Low values of some important trace element ratios like Th/La, $\mathrm{Nb} / \mathrm{Y}$ rule out the possible effects of crustal contamination during the evolution of NDD. The Th/ La ratio is an index of crustal contamination (Sun and McDonough 1989) and distinct low values of $\mathrm{Th} / \mathrm{La}$ of NDDs $(0.07-0.20)$ close to primitive mantle value $(\sim 0.12$; Sun and McDonough 1989) rule out the possibility of crustal contamination. Also, the $\mathrm{Nb} / \mathrm{Y}$ ratio ranges between 0.1 and 0.4 which is significantly lower than the continental crust ( $\sim 0.7$, Weaver and Tarney 1984). When dolerite samples are plotted in the $\mathrm{Th} / \mathrm{Yb}$ vs. $\mathrm{Nb} / \mathrm{Yb}$ diagram (figure 11) (Pearce 2008), few sample plots are plotted in and around the mantle array, but most of the samples are plotted above the mantle array along a vertical to subvertical trend, indicating the involvement of a subduction 


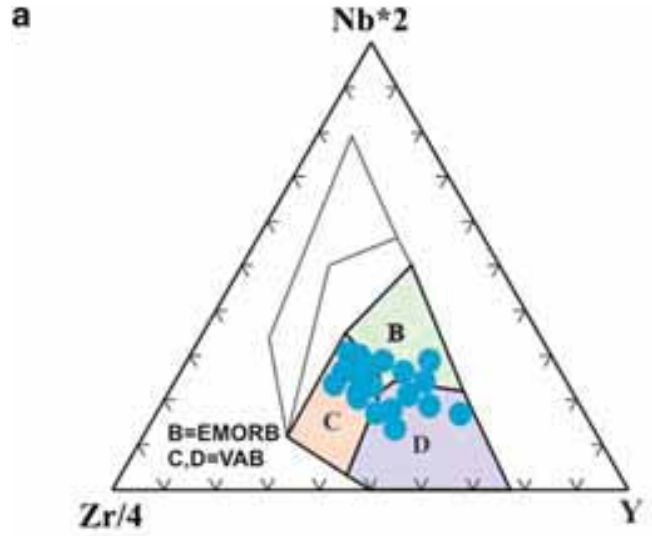

b
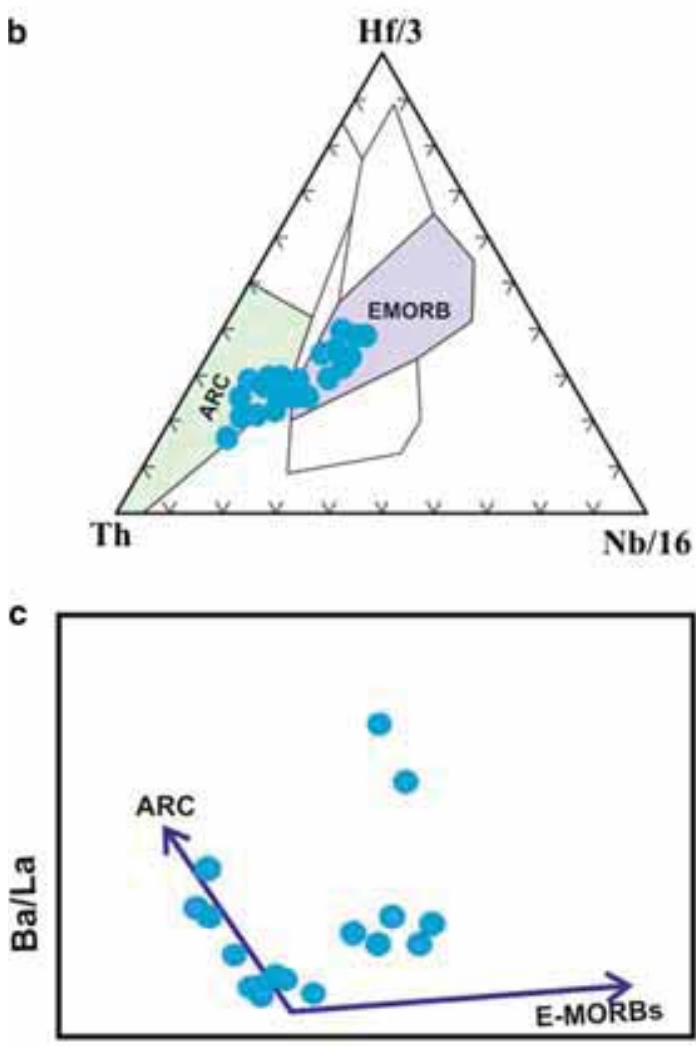

$\mathrm{Nb} / \mathrm{La}$

Figure 10. Geochemical diagrams: (a) Nb-Zr-Y (after Meschede 1986), (b) Hf-Th-Nb (After Wood 1980) and (c) $\mathrm{Ba} / \mathrm{La}$ vs. Nb/La (after Escrig et al. 2009) suggesting arc-like geochemical characteristics of the NDD sample plots. Symbols are the same as in figure 5 .

component during petrogenesis. The continental crust is plotted far away from these sample plots and there is no possibility of any crustal contamination.

\subsection{Source mantle heterogeneity}

Different trace elements and REE ratios are important tools to identify the status of the mantle source region. The enrichment of fluid

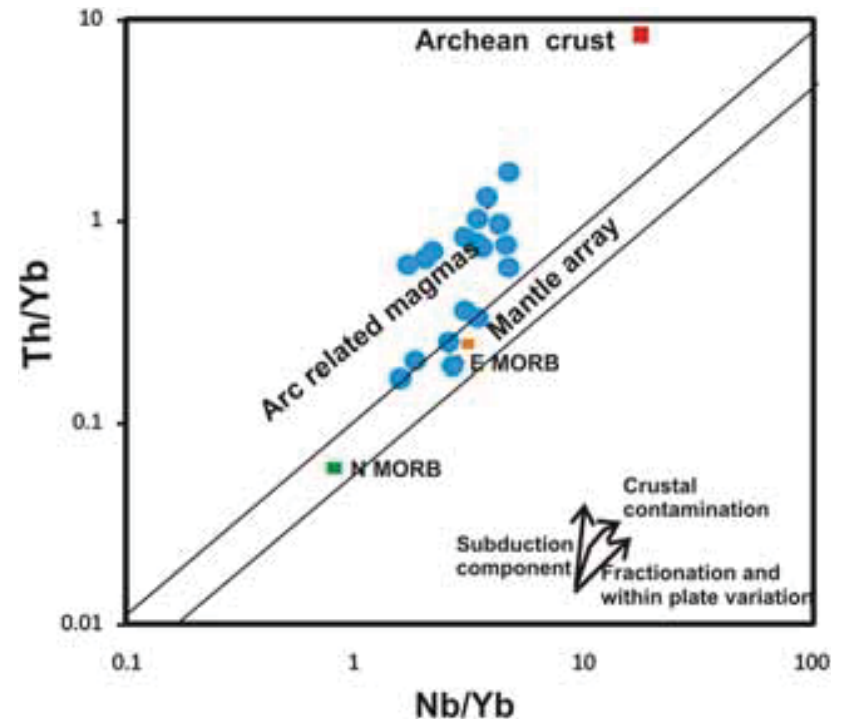

Figure 11. Th/Yb vs. Nb/Yb diagram (after Pearce 2008; Szilas et al. 2016) showing the plots of the majority of NDD falling in the region of arc-related magmas, a few fall in the field for E-MORB. The sample plots are displaced along a linear trend away from the mantle array which signifies the influence of subduction components like fluid, melts, etc., in the source of these dolerites.

mobile elements and LILEs such as Rb, Ba, Th, $\mathrm{K}$ and La suggest the probable addition of components like sediments and fluids which carry these elements to the mantle source (Kepezhinkas et al. 1997) prior to melting. In the $\mathrm{Nb} / \mathrm{Y}$ vs. $\mathrm{Ba} / \mathrm{Y}$ (figure $12 \mathrm{a}$ ) and $\mathrm{Nb} / \mathrm{Zr}$ vs. $\mathrm{Th} / \mathrm{Zr}$ diagrams (figure 12b), the NDD samples define trends which are consistent with the evolutionary trend of the source mantle modified by fluid phases and melt (Kepezhinkas et al. 1997; La Fleche et al. 1998). In the $\mathrm{Sm} / \mathrm{La}$ vs. Th/La diagram (figure 12c), all the dolerite samples are plotted in the arc magma array with some dolerite plots very close to the global subducting sediment (GLOSS) (Plank and Langmuir 1998), indicating the influence of sediments/melt during the generation of these dolerite dykes. In the (Hf/Sm) $n$ vs. (Ta/La)n diagram (figure 12d, La Fleche et al. 1998), it is observed that the samples of the dolerite dykes fall very close to the fields of fluid-induced metasomatism and melt-induced metasomatism of the subduction zone. It is therefore quite evident from all these diagrams that the source mantle has been metasomatised due to the variable mixing of inputs from both fluid and melt from different parts of the subduction zone.

Both the composition of the mantle source and the degree of partial melting that produced the 

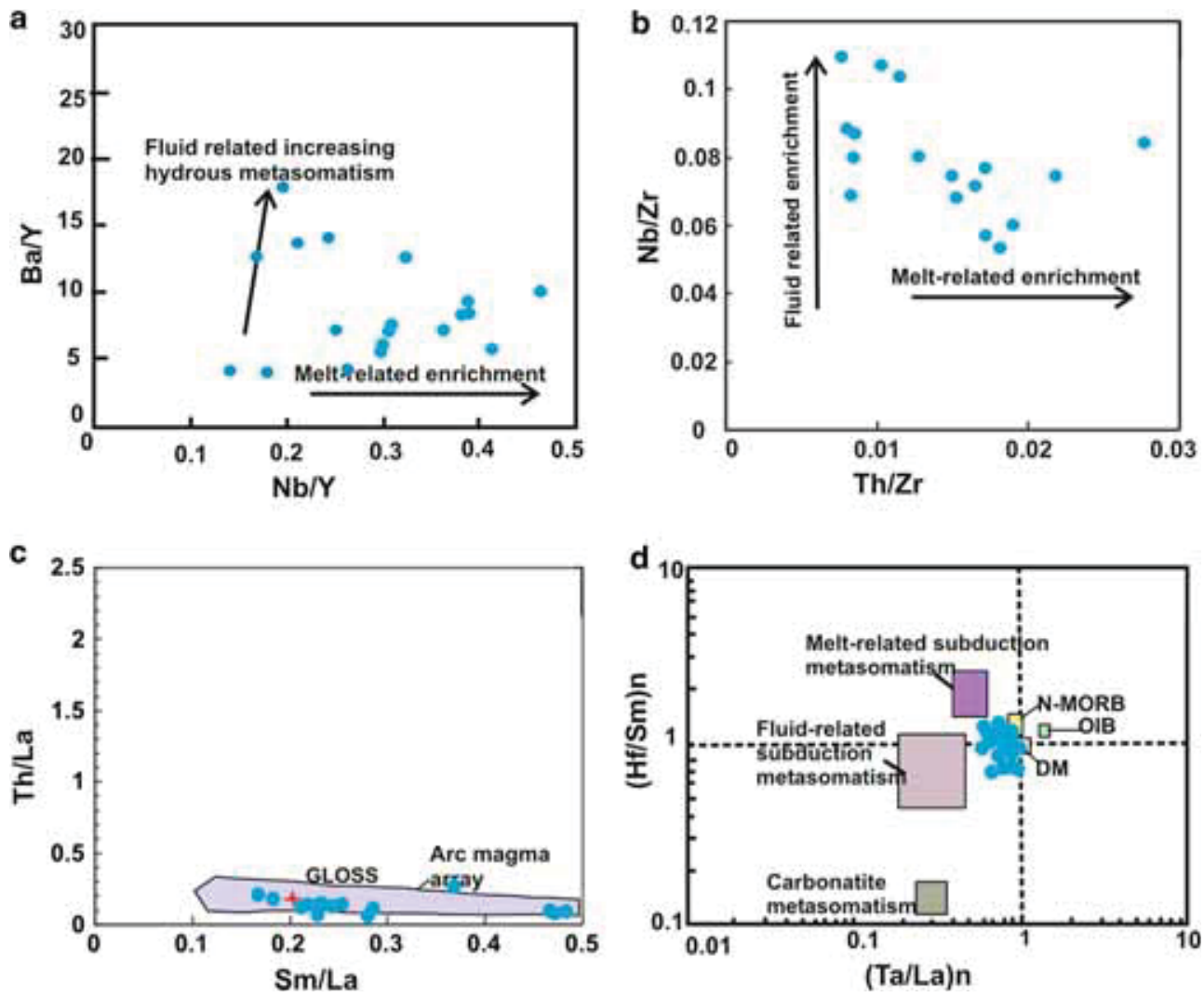

Figure 12. (a) Plots of Nb/Y vs. Ba/Y (after La Fleche et al. 1998), (b) Nb/Zr vs. Th/Zr (after Kepezhinkas et al. 1997) for NDD, suggesting that the source of these dykes has undergone both fluid-related and melt-related metasomatism, (c) Sm/La vs. Th/La (after Tommasini et al. 2011) showing the composition of NDD occupying the region for arc magma of Plank (2005) very close to the GLOSS (Plank and Langmuir 1998) and (d) in (Hf/Sm) $n$ vs. (Ta/La) $n$ diagram (after La Fleche et al. 1998) NDD samples fall very close to fields of fluid-induced metasomatism and melt-induced metasomatism of the subduction zone. NDD symbols are the same as in figure 5 .

parental magmas of these dolerites can be determined using REE abundances and ratios. In the $(\mathrm{La} / \mathrm{Sm})_{C}$ vs. $(\mathrm{Gd} / \mathrm{Yb})_{C}$ diagram (figure 13a), the disposition of sample plots suggests their origin from a spinel-bearing source displaying variations of degrees of melting and/or source enrichment. In the $\mathrm{La} / \mathrm{Sm}$ vs. La diagram (figure 13b), it is observed that a majority of the samples (13 samples) are plotted along trends of both partial melting and fractional crystallisation while few samples (six) are plotted as a cluster possibly affected by partial melting only. To determine the partial melting of the source, we used the $\mathrm{Sm} / \mathrm{Yb}$ vs. Sm diagram (Zhao and Zhou 2007). The partial melting of a spinel peridotite mantle source does not change the $\mathrm{Sm} / \mathrm{Yb}$ ratio because both $\mathrm{Sm}$ and $\mathrm{Yb}$ have similar partition coefficients, whereas it may decrease the Sm contents of the melts (Aldanmaz et al. 2000). It is found that the dolerites crystallised from melts derived by $5-30 \%$ melting of the spinel lherzolite source (figure 13c).

\subsection{REE modelling}

It has been proposed earlier that the spinel peridotitic mantle source of the NDD has been modified by fluid and melt-induced metasomatism prior to melting. Metasomatism may lead to variable degrees of modification of the spinel peridotite source (Fabries et al. 1989; Yaxley et al. 1991). In subduction zones, the effects of the reaction between fluids, melts and peridotitic mantle conceivably depend upon the character of the fluid/ melt and 'effective' melt-rock ratio (Rappa et al. 1999), and accordingly, the different mineral phases may remain intact, or change to different assemblages (Neumann 1991; Yaxley et al. 1991; Sen and Dunn 1995).

We attempted a REE modelling of the dyke samples which have shown distinct effects of fractional crystallisation and partial melting in binary diagrams (figure 7a-d). For this purpose, we are considering three different sources: (i) an 


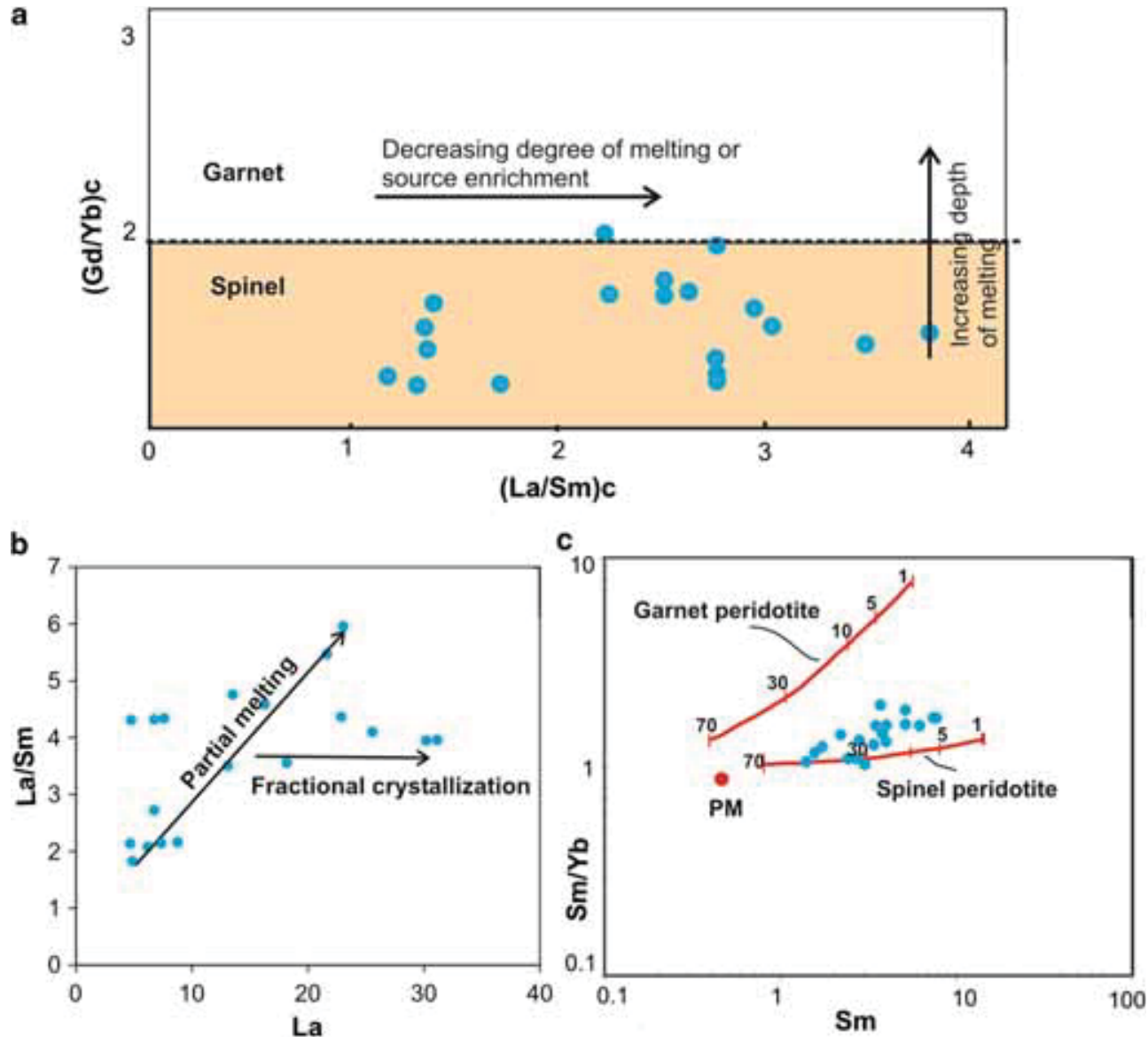

Figure 13. (a) $(\mathrm{La} / \mathrm{Sm}) c$ vs. $(\mathrm{Gd} / \mathrm{Yb}) c$ diagram shows that all the NDD samples are plotted in the field of spinel peridotite. Normalisation values of the chondrite C1 after Sun and McDonough (1989), (b) the La vs. La/Sm diagram indicates that majority of the NDD samples have suffered both partial melting and fractional crystallisation during evolution and (c) Sm/Yb vs. Sm plot (after Zhao and Zhou 2007) shows that NDD have been generated by 5-30\% partial melting of a spinel peridotite source.

unmodified spinel lherzolite source from an arc setting; (ii) a metasomatised spinel peridotite source 1; (iii) another metasomatised spinel peridotite source 2 . To calculate the distribution coefcients of the rock, its modal assemblage and mineral/melt partition coefficients were utilised (table 4). Modal mineralogy of these three different mantle sources is shown in table 5. Firstly, we started the REE modelling considering spinel lherzolite as a probable mantle source from arc setting (different compositions of spinel lherzolite were taken from GEOROC, http://georoc.mpchmainz.gwdg.de; series 6906; phase proportions are shown in table 5) and run the program with a variable degree of partial melting $(F=0.05-0.25)$ along with $30 \%$ fractionation of an assemblage consisting of $40 \%$ olivine, $40 \%$ clinopyroxene and $20 \%$ orthopyroxene. We considered our degree of partial melting within a limit of $F=0.05-0.25$ because such relatively higher degree of melting
Table 4. Distribution coefficient (Kd) of different mineral phases used during REE modelling (Ol: Bedard (2005); Cpx and Opx: Chakraborti et al. (2016); Cr Spl: Nagasawa et al. (1980)).

\begin{tabular}{lllll}
\hline $\mathrm{Kd}$ & \multicolumn{1}{c}{$\mathrm{Ol}$} & $\mathrm{Cpx}$ & \multicolumn{1}{c}{ Opx } & Cr-Spl \\
\hline $\mathrm{La}$ & 0.009683 & 0.08 & 0.0003 & 0.01 \\
$\mathrm{Ce}$ & 0.007004 & 0.14 & 0.0005 & 0.01 \\
$\mathrm{Nd}$ & 0.004327 & 0.177 & 0.049 & 0.01 \\
$\mathrm{Sm}$ & 0.002694 & 0.32 & 0.024 & 0.0064 \\
$\mathrm{Eu}$ & 0.006295 & 0.59 & 0.02 & 0.0061 \\
$\mathrm{Gd}$ & 0.003423 & 0.325 & 0.1 & 0.01 \\
$\mathrm{~Tb}$ & 0.009046 & 0.42 & 0.06 & 0.0078 \\
$\mathrm{Dy}$ & 0.008724 & 0.42 & 0.3 & 0.01 \\
$\mathrm{Er}$ & 0.02133 & 0.66 & 0.083561 & 0.01 \\
$\mathrm{Yb}$ & 0.027088 & 0.59 & 0.14 & 0.0076 \\
$\mathrm{Lu}$ & 0.048975 & 0.449 & 0.43 & 0.02 \\
\hline
\end{tabular}

of mantle source can only account for the huge volumes of NDD spread throughout the Singhbhum craton. The REE patterns generated due to 
the variable degree of partial melting and fractionation of the spinel lherzolite source has been compared with the REE pattern of the representative NDD sample of the study area. The REE patterns of the derived melts generated due to the variable degree of melting and fractionation of the lherzolitic source are completely different and of much lower abundance when compared with the representative NDD of the study area (figure 14).

Secondly, we performed REE modelling considering a metasomatised spinel peridotite 1 as a probable mantle source from arc setting which (two different compositions of metasomatised spinel peridotite were taken from GEOROC, http:// georoc.mpch-mainz.gwdg.de; series 8833; phase proportions shown in table 5) and run the program with the same variable degree of partial melting $(F=0.05-0.25)$ and fractionation as in the previous case. The REE patterns generated due to the variable degree of partial melting $(F=0.05-0.25)$ of the metasomatised spinel peridotite 1 source have been compared with the REE patterns of the representative NDD samples of the study area. The REE patterns of the derived melts generated due to a variable degree of melting and fractionation of metasomatised peridotite 1 are completely different and of much higher abundance when compared with the representative NDD of the study area (figure 14). In the first and second attempts, we have compared one unmodified spinel lherzolite source and one metasomatised spinel peridotite source 1 from arc settings but the REE pattern of derived melts and observed dolerites did not match. In our third attempt, we considered another metasomatised peridotite 2 as a probable mantle source (composition of spinel peridotite was taken from GEOROC http://georoc.mpch-mainz.gwdg. de; no: 10399). Here, we found that the REE patterns of derived melts generated by $5-25 \%$ melting of this source along with $30 \%$ fractionation of an

Table 5. Modal mineralogy of different mantle source rocks.

\begin{tabular}{lccccc}
\hline & \multicolumn{4}{c}{ Phase proportion of source rocks being melted } \\
\cline { 2 - 6 } Source rock & Olivine & Clinopyroxene & Orthopyroxene & Plagioclase & Crome-Spinel \\
\hline Unmodified spinel lherzolite & 60 & 8 & 30 & 0 & 2 \\
Metasomatised spinel peridotite 1 & 55 & 8 & 35 & 0 & 2 \\
Metasomatised spinel peridotite 2 & 70 & 30 & 0 & 0 & 0 \\
\hline
\end{tabular}

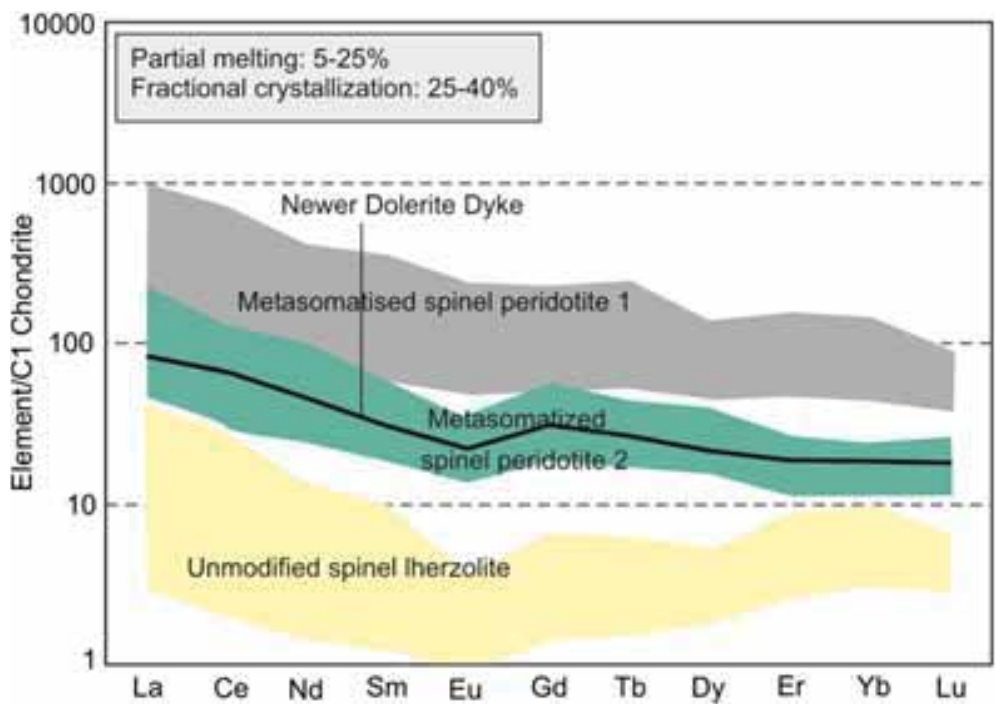

Figure 14. Chondrite normalised REE diagram showing a REE pattern of hypothetically derived parent melts generated by $5-25 \%$ melting of three different sources along with $30 \%$ fractionation of an assemblage consisting of $40 \%$ olivine, $40 \%$ clinopyroxene and $20 \%$ orthopyroxene: (i) the field coloured yellow represents REE patterns generated by the melting of an unmodified spinel lherzolite source which shows an overall much lower abundance and different pattern than the representative NDD sample (marked in black), (ii) the field coloured grey represents REE patterns generated by the melting of a metasomatised spinel peridotite 1 which shows a much higher abundance than the representative NDD sample (marked in black), (iii) the field coloured green represents REE patterns generated by the melting of another metasomatised spinel peridotite 2 . It is observed that the REE pattern generated by the melting of this metasomatised spinel peridotite 2 source followed by fractionation matches very well with the REE pattern and abundance of the representative NDD (shown in black colour). For details, see text. 
assemblage consisting of $40 \%$ olivine, $40 \% \mathrm{Cpx}$ and $20 \%$ Opx is very similar to the REE pattern of the representative NDD sample (figure 14).

\section{Discussion}

The present investigation focuses on mafic dykes emplaced within the Singhbhum granite in the central part of the Singhbhum craton around the north of Bahalda. The mafic dykes show a dominant NE-SW trend. Petrographic studies show that these dykes are essentially composed of clinopyroxene and plagioclase and at places clinopyroxenes are variably replaced by chlorite, tremolite and actinolitic amphibole. Plagioclase occurs mostly as clouded grains showing a patchy appearance. The presence of actinolitic amphibole, bastitised orthopyroxene and clouded plagioclase suggest the hydrothermal alteration of the dolerite under low grade metamorphism (Sengupta and Ray 2012).

Dolerites are silica saturated to oversaturated tholeiitic basalt and range in composition from basalt to basaltic andesite. LILEs like $\mathrm{Rb}, \mathrm{Ba}, \mathrm{Sr}$ and Th show pronounced variation in abundances. In the chondrite normalised REE plot, the majority of 13 dykes show an enrichment of LREE over HREE while few dykes (six) show a relatively flat pattern with slight enrichment of LREE. Enrichment of large-ion lithophile elements like $\mathrm{Ba}, \mathrm{Rb}$, $\mathrm{K}$, Sr, variable enrichment of LREEs (La, Ce, Pr) over HREEs and distinct negative anomaly at $\mathrm{Nb}$, $\mathrm{P}$, Ti suggest that these NDDs have been generated from a heterogeneous mantle source (Wilson 1989). Plots of dolerite dykes in Nb-Zr-Y, Hf-Th-Nb and $\mathrm{Ba} / \mathrm{La}$ vs. Nb/La diagrams suggest that the rocks of NDD have geochemical characteristics similar to arc/backarc lava basalt.

The dykes do not show significant effect of crustal contamination as indicated by the $\mathrm{Th} / \mathrm{Yb}$ vs. $\mathrm{Nb} / \mathrm{Yb}$ diagram (figure 11) (Pearce 2008) and some important trace element ratios like Th/La, $\mathrm{Nb} / \mathrm{Y}$, etc. A study of several significant trace element ratios like $\mathrm{Ba} / \mathrm{La}, \mathrm{La} / \mathrm{Sm}, \mathrm{Nb} / \mathrm{Y}, \mathrm{Ba} / \mathrm{Y}$, $\mathrm{Nb} / \mathrm{Zr}, \mathrm{Th} / \mathrm{Zr}, \mathrm{Sm} / \mathrm{La}, \mathrm{Th} / \mathrm{La}, \mathrm{La} / \mathrm{Sm}, \mathrm{Gd} / \mathrm{Yb}$ and $\mathrm{Sm} / \mathrm{Yb}$ indicates that the dolerite dykes originated from a heterogeneous spinel peridotite mantle source which was modified by fluids and melts (figure 12). REE modelling of these dolerite dykes shows that a representative of NDD has been generated by $5-30 \%$ melting of a metasomatised spinel peridotite source (GEOROC; no. 10399) along with $30 \%$ fractionation of an assemblage consisting of $40 \%$ olivine, $40 \%$ clinopyroxene and $20 \%$ orthopyroxene.

Recent age data suggest a Neoarchaean age ( 2800 my) as proposed by Kumar et al. (2017) for few NNE-SSW trending NDD within the Singhbhum granite. Recently, Srivastava et al. (2018) divided these NDDs into seven major swarms, ranging in age from $\sim 2.80 \mathrm{Ga}$ (Neoarchaean) to $\sim 1.76 \mathrm{Ga}$ (Palaeoproterozoic). However, they only dated four of these swarms while the other three swarms were distinguished on the basis of their trend and cross-cutting relationships with other dykes and country rocks. The NDDs of our present study fall within the NNE-SSW to NE-SW trending Ghatgaon swarm with an age of $\sim 2.75-2.76 \mathrm{Ga}$. Regarding the origin and emplacement of the NDDs in the northern part of the Singhbhum craton which shows ages from 2.7 to $2.8 \mathrm{Ga}$ (Kumar et al. 2017; Srivastava et al. 2018), we can consider the genetic model of Dunn and Dey (1942) which suggests an underplating of a subcrustal lithosphere of the Singhbhum craton by mantle-derived basic magma and its subsequent upliftment along a pre-existing fracture due to isostatic sagging. This process might have been responsible for the generation of all the dykes of NNE-SSW to NE-SW trends within the northern part of the Singhbhum granite during a single episode which seems to be around 2.7-2.8 Ma. Mafic magma underplating of the continental crust in the arc and rift setting may have been a key process in the growth of the continental crust, specially in the Archaean (Fyfe 1978, 1992; Thybo and Artemieva 2013). Crustal heating caused by underplating and mafic intrusions causes crustal melting and is followed by a granitic magmatism (e.g., Huppert and Sparks 1988; Douce 1999; Coldwell et al. 2011; He et al. 2011). The $2800 \mathrm{Ma}$ magmatic event responsible for the origin of NDD appears to be contemporaneous with major scale anorogenic granitic activity in the Singhbhum craton. The Budhapal granite $(2807 \pm 13 \mathrm{Ma}$; U-Pb zircon age, Bose et al. 2016) on the south-western margin of the craton, the Rengali granite $(2803 \pm 4$ and $2811 \pm 3 \mathrm{Ma}$; U-Pb zircon age, Misra et al. 1999) from the southern parts of the craton, the Temperkola granite $(2809 \pm 12 \mathrm{Ma}$; U-Pb zircon age, Bandyopadhyay et al. 2001) from the western periphery of the craton have petrological and geochemical characteristics similar to A-type granite. The voluminous NDD and contemporaneous A-type granites of 2800 Ma age mark a major event 
of magmatic activity in the Singhbhum craton and an important event of crust-mantle interaction.

\section{Conclusions}

1. This study focused on the NE-SW to NNESSW trending NDDs around Bahalda emplaced within the Singhbhum granite, Singhbhum craton.

2. The dolerites show hydrothermal alteration under low grade metamorphism as evidenced by the presence of actinolitic amphibole, bastitised orthopyroxene and clouded plagioclase.

3. In the chondrite normalised REE plot, the majority of 13 dykes show an enrichment of LREE over HREE while few dykes (six) show a relatively flat pattern with a slight enrichment of LREE.

4. The NDDs of Bahalda region have geochemical characteristics similar to the arc/backarc basalt as evidenced from several diagrams using variable compatible/incompatible element concentrations and their ratios.

5. The dolerites originated from a heterogeneous spinel peridotite mantle source which was modified by both fluids and melts.

6. REE modelling of these dolerite dykes show that they have been generated by $5-30 \%$ melting of a metasomatised spinel peridotite source (GEOROC; no. 10399) along with 30\% fractionation of an assemblage consisting of $40 \%$ olivine, $40 \% \mathrm{Cpx}$ and $20 \% \mathrm{Opx}$.

7. The NDD of our present study falls within the area of NNE-SSW to NE-SW trending Ghatgaon swarm of NDD with an age of $\sim 2.75-2.76$ Ga (Srivastava et al. 2018). The 2800 Ma magmatic event seems to be responsible for the origin of these NDDs along with contemporaneous A-type granites marking a major event of magmatic activity in the Singhbhum craton.

\section{Acknowledgements}

The authors would like to thank the Department of Science and Technology (DST), New Delhi, India for providing the funds to carry out this research work (grant No. SR/WOS-A/ES-22/2012(G), Dated: 23.5.2013). The authors would also like to thank the Head, Department of Geology,
Presidency University for providing the infrastructural support. The second author would like to thank Presidency University for providing the FRPDF grant.

\section{References}

Acharyya S K 1993 Greenstones from Singhbhum Craton, their Archaean character, oceanic crustal affinity and tectonics; Proc. Nat. Acad. Sci., India 63 211-222.

Aldanmaz E, Pearce J A, Thirlwall M F and Mitchell J G 2000 Petrogenetic evolution of late Cenozoic, post-collision volcanism in western Anatolia, Turkey; J. Volcanol. Geotherm. Res. 102 67-95.

Bandyopadhyay P K, Chakrabarti A K, DeoMurari M P and Misra S 20012.8 ga old anorogenic granite-acid volcanics association from Western margin of the Singhbhum-Orissa Craton, Eastern India; Gondwana Res. 4 465-475.

Bedard J H 2005 Partitioning coefficients between olivine and silicate melts; Lithos 83 394-419.

Bleeker W and Ernst R E 2006 Short-lived mantle generated magmatic events and their dyke swarms: The key unlocking Earth's paleogeographic record back to $2.6 \mathrm{Ga}$; In: Dyke swarms - Time markers of crustal evolution (eds) Hanski E, Mertanen S, Rämö T and Vuollo J, Taylor \& Francis, London, pp. 3-26.

Bose M K 2000 Mafic-ultramafic magmatism in the eastern Indian Craton - A review; Geol. Surv. India, Spec. Publ. $\mathbf{5 5}$ 227-258.

Bose M K 2008 Proterozoic dykes from Singhbhum granite pluton; In: Indian dykes (eds) Srivastava S and Rao C, Narosa Publication, New Delhi, pp. 413-445.

Bose M K, Chakraborti M K and Saunders A D 1989 Geochemistry of the lavas from Proterozoic Dalma volcanic belt, Singhbhum, Eastern India; Geol. Rundchau. 70 504-518.

Bose S, Das K, Kimura K, Hidaka H, Dasgupta A, Ghosh G and Mukhopadhyay 2016 Neoarchean tectonothermal imprints in the Rengali Province, eastern India and their implication on the growth of Singhbhum Craton: Evidence from zircon U-Pb SHRIMP data; J. Metamorph. Geol. 34 $743-764$.

Cadman A C, Heamn L, Tarney J, Wardle R and Krogh T E 1993 $\mathrm{U}-\mathrm{Pb}$ geochronology and geochemical variation within two Proterozoic mafic dyke swarms, Labrador; Can. J. Earth Sci. 30 1490-1504, https://doi.org/10.1139/e93-128.

Chakraborti T M, Ray A and Deb G K 2016 Computation of parent magma compositions of a Layered Gabbro Suite around Kuliana, Orissa, Eastern India: Implications for magmatic evolution and paleotectonic setting; J. Geol. 124 723-741.

Coffin M F and Eldholm O 1994 Large igneous provinces: Crustal structure, dimensions, and external consequences; Rev. Geophys. 32 1-36.

Coldwell B, Clemens J and Petford N 2011 Deep crustal melting in Peruvian Andes: Felsic magma generation during delamination and uplift; Lithos 125(1-2) $272-286$.

Dostal J, Keppie J D and Murphy J B 1990 Geochemistry of Late Proterozoic basaltic rocks from southeastern Cape Breton Island, Nova Scotia; Can. J. Earth Sci. 27 619-631. 
Douce A E P 1999 What do experiments tell us about the relative contributions of crust and mantle to the origin of granitic magmas? Geol. Soc. London Spec. Publ. 168 $55-75$.

Dunn J A 1929 The geology of north Singhbhum including parts of Ranchi and Manbhum districts; Mem. Geol. Surv. India 54(2) 1166.

Dunn J A and Dey A K 1942 Geology and petrology of Eastern Singhbhum and surrounding areas; Mem. Geol. Surv. India 69(2) 261-456.

Escrig S, Bézos A, Goldstein S L, Langmuir C H and Michael P J 2009 Mantle source variations beneath the Eastern Lau Spreading Center and the nature of subduction components in the Lau basin-Tonga arc system; Geochem. Geophys. Geosyst. 10(4) 1-33.

Ewart A, Collerson K D, Regelous M, Wendt J I and Niu Y 1998 Geochemical evolution within the Tonga-Kermadec Lau arc back-arc systems: The role of varying mantle wedge composition in space and time; J. Pet. 39 $331-368$

Ernst R E 2014 Large igneous provinces; Cambridge University Press, Cambridge, 653p.

Ernst R E, Bleeker W, Söderlund U and Kerr A C 2013 Large igneous provinces and supercontinents: Toward completing the plate tectonic revolution; Lithos 174 1-14.

Evans D A D 2013 Reconstructing pre-Pangean supercontinents; Geol. Soc. Am. Bull. 125 1735-1751.

Fabries J, Bodinier J L, Dupuy C, Lorand J P and Benkerrou C 1989 Evidence for modal metasomatism in the erogenic spinel lherzolite body from Caussou (Northeastern Pyrenees, France); J. Pet. 30 199-228.

Fyfe W S 1978 Evolution of earth's crust-modern plate tectonics to ancient hot spot tectonics; Chem. Geol. 23 89-114.

Fyfe W S 1992 Magma underplating of continental- crust; $J$. Volcanol. Geotherm. Res. 50 33-40.

Govindaraju K 1994 Compilation of working values and sample description for 383 geostandards newsletter; $J$. Geostand. Geoanal. 18158.

Halls H 2008 The importance of integrating paleomagnetic studies of proterozoic dykes with $\mathrm{U}-\mathrm{Pb}$ geochronology and geochemistry; In: Indian dykes: Geochemistry, geophysics and geochronology (eds) Srivastava R K, Sivaji C and Rao N V C, Narosa Publishing House Pvt. Ltd., New Delhi, India, pp. 1-22.

He Y, Li S, Hoefs J, Huang F, Liu S and Hou Z 2011 Postcollisional granitoids from the double orogen: New evidence for partial melting of a thickened crust; Geochim. Cosmochim. Acta 75(13) 3815-3838.

Huppert H E and Sparks R S J 1988 The generation of granitic magmas by intrusion of basalt into the continental crust; J. Pet. 29 599-624.

Irvine T A and Baragar W R A 1971 A guide to chemical classification of common volcanic rocks; Can. J. Earth Sci. 8 523-548.

Jones H C 1934 The iron ore deposits of Bihar and Orissa; Geol. Surv. India Mem. 63(2) 167-302.

Kepezhinkas P, McDermott F, Defant M J, Hochstaedter A and Drummond M S 1997 Trace element and Sr-Nd-Pb isotopic constraints on a three component model of Kamchatka Arc petrogenesis; Geochim. Cosmochim. Acta 61(3) 577-600.

Krishnan M S 1936 The dyke rocks of Keonjhar state, Bihar and Orissa; Rec. Geol. Surv. India 71 105-120.
Kumar A, Parashuramulu V, Shankar R and Besse J 2017 Evidence for a Neoarchean LIP in the Singhbhum Craton, eastern India: Implications to Vaalbara supercontinent; Precamb. Res. 292 163-174.

La Fleche M R, Camire G and Jenner G A 1998 Geochemistry of post-Acadian, Carboniferous continental intraplate basalts from the Maritimes Basin, Magdalen islands, Quebec, Canada; Chem. Geol. 148 115-136.

Le Bas M J 2000 IUGS reclassification of the high-Mg and picritic volcanic rocks; J. Pet. 41 1467-1470.

Mahadevan T M 2002 Geology of Bihar and Jharkhand; Geol. Soc. India Bangalore, 563p.

Maity B, Ray J, Chattopadhyay B, Sengupta S, Nandy S and Saha S 2008 Contrasting petrological variants in newer Dolerite dyke swarm Around Bisoi, Eastern Indian shield: Insights from petrography and mineral chemistry; In: Indian dykes: Geochemistry, geophysics and geochronology (eds) Srivastava R K, Sivaji C H and Chalapathi Rao N V, Narosa Publishing House Pvt. Ltd., New Delhi, pp. $447-470$.

Mallik A K and Sarkar A 1994 Geochronology and geochemistry of mafic dykes from the Precambrians of Keonjhar, Orissa; Indian Miner. 48 13-24.

Mandal N, Mitra A K, Misra S and Chakraborty C 2006 Is the outcrop topology of dolerite dikes of the Precambrian Singhbhum Craton fractal? J. Earth Syst. Sci. 115(6) 643-660.

Manikyamba C, Ray J, Ganguly S, Singh M R, Santosh M, Saha A and Satyanarayanan M 2015 Boninitic metavolcanic rocks and island arc tholeiites from the Older Metamorphic group (OMG) of Singhbhum Craton, Eastern India: Geochemical evidence for Archean subduction processes; Precamb. Res. 271 138-159.

Meschede M 1986 A method of discriminating between different types of mid-ocean ridge basalts and continental tholeiites with the Nb-Zr-Y diagram; Chem. Geol. 56 207-218.

Mir A R, Alvi S H and Balaram V 2010 Geochemistry of mafic dikes in the Singhbhum Orissa Craton: Implications for subduction-related metasomatism of the mantle beneath the eastern Indian Craton; Int. Geol. Rev. 52 79-94.

Mir A R, Alvi S H and Balaram V 2011 Geochemistry of the mafic dykes in parts of the Singhbhum granitoid complex: Petrogenesis and tectonic setting; Arabian J. Geosci. 4 933-943.

Misra S 2006 Precambrian chronostratigraphic growth of Singhbhum-Orissa Craton, Eastern Indian Shield: An alternative model; J. Geol. Soc. India 67 356-378.

Misra S, Moitra S, Bhattacharya S and Shivaraman T V 1999 Archaean granitoids at the contact of Eastern Ghats Granulite Belt and Singhbhum-Orissa Craton in Bhuban-Rengali sector, Orissa, India; Gondwana Res. 3 205-213.

Mukhopadhyay D 2001 The Archean nucleus of Singhbhum: The present state of knowledge; Gondwana Res. 4 307-318.

Mukhopadhyay J, Ghosh G, Zimmermann U, Guha S and Mukherjee T 2012 A 3.51 Ga bimodal volcanics-BIFultramafic succession from singhbhum Craton: Implications for Paleoarchean geodynamic processes from the oldest greenstone succession of the Indian sub-continent; Geol. J. $47284-311$. 
Nagasawa H, Schreiber H D and Morris R V 1980 Experimental mineral/liquid partition coefficients of the rare earth elements/REE/, SC and SR for perovskite, spinel and melilite; Earth Planet. Sci. Lett. 46 431-437.

Nelson D R, Bhattacharyaa H N, Thernb E R and Altermann W 2014 Geochemical and ion-microprobe U-Pb zircon constraints on the Archaean evolution of Singhbhum Craton, eastern India; Precamb. Res. 255 412-432.

Neumann R 1991 Ultramafic and mafic xenoliths from Hierro, Canary islands: Evidence for melt infiltration in the upper mantle; Contrib. Mineral. Petrol. 106(2) 236-252.

Pearce J 1983 Role of sub-continental lithosphere in magma genesis at active continental margin; In: Continental basalts and mantle xenoliths (eds) Hawkesworth C J and Norry M J, Shiva, Nantwich, pp. 230-249.

Pearce J 1996 A users guide to basalt discrimination diagrams; In: Trace element geochemistry of volcanic rocks: Applications for massive sulfide exploration: Geological association of Canada, short course notes (ed.) Wyman D A, Vol. 12, pp. 79-113.

Pearce J A 2008 Geochemical fingerprinting of oceanic basalts with applications to ophiolite classification and the search for Archean oceanic crust; Lithos 100 14-48.

Peate D W, Kokfelt T F, Hawkesworth C J, Van Calsteren P W, Hergt J M and Pearce J A 2001 U-series isotope data on Lau basin glasses: The role of subduction related fluids during melt generation in back-arc basins; J. Pet. 42 1449-1470.

Pisarevsky S A, Biswal T K, Wang X-C, De Waele B, Ernst R, Söderlund U, Tait J A, Ratre K, Singh Y K and Cleve M 2013 Palaeomagnetic, geochronological and geochemical study of Mesoproterozoic Lakhna Dykes in the Bastar Craton, India: Implications for the Mesoproterozoic supercontinent; Lithos 174 125-143.

Plank T 2005 Constraints from thorium/lanthanum on sediment recycling at subduction zones and the evolution of the continents; J. Petrol. 46 921-944.

Plank T and Langmuir C H 1998 The geochemical composition of subducting sediment and its consequences for the crust and mantle; Chem. Geol. 145 325-394.

Poldervaart A and Gilkey A K 1954 On clouded plagioclase; Am. Mineral. 39(1-2) 75-91.

Rappa R P, Shimizu N, Normanc M D and Applegatead G S 1999 Reaction between slab-derived melts and peridotite in the mantle wedge: Experimental constraints at $3.8 \mathrm{GPa}$; Chem. Geol. 160 335-356.

Regelous M K, Collerson D, Ewart A and Wendt J I 1997 Trace element transport rates in subduction zones: Evidence from $\mathrm{Th}, \mathrm{Sr}$ and $\mathrm{Pb}$ isotope data for Tonga-Kermadec arc lavas; Earth Planet. Sci. Lett. 150 291-302.

Roy A, Sarkar A, Jeyakumar S, Aggarwal S K, Ebihara M and Satoh H 2004 Late Archaean mantle metasomatism below eastern Indian Craton: Evidence from trace elements, REE geochemistry and $\mathrm{Sr}-\mathrm{Nd}-\mathrm{O}$ isotope systematics of ultramafic dykes; Earth Planet. Sci. Lett. 113 649-665.

Saha A K 1949 Dolerite dykes and sills around Chaibasa; $Q$. J. Geol., Min. Metall. Soc. India 21 77-83.

Saha A K 1952 On porphyry dykes near Dalsara, Mayurbhanj; Sci. Culture 18 250-258.

Saha A K 1994 Crustal evolution of North Singhbhum-Orissa, eastern India; Geol. Soc. India Mem. 27 341p.
Saha A K, Sankaran A V and Bhattacharyya T K 1973 Geochemistry of the newer dolerite suite of intrusions within the Singhbhum granite; Geol. Soc. India 14 324-346.

Samal A K, Srivastava R K, Ernst R E and Sodurland U 2019 Neoarchean-Mesoproterozoic Mafic Dyke Swarms of the Indian shield mapped using Google Earth (images and ArcGIS" and links with large igneous province; In: Dyke swarms of the world: A modern perspective (eds) Srivastava R, Ernst R and Peng P, Springer Geology, Springer, Singapore, pp. 335-390.

Sarkar S N and Saha A K 1977 The present status of the Precambrian stratigraphy, tectonics and geochronology of Singhbhum-Keonjhar-Mayurbhanj region, Eastern India; Indian J. Earth Sci. 4 37-65.

Sarkar S N, Saha A K and Miller J A 1969 Geochronology of the Pre-Cambrian rocks of Singhbhum and adjacent regions, Eastern India; Geol. Mag. 106 15-45.

Shankar R, Vijayagopal B and Kumar A 2014 Precise Pb-Pb baddeleyite ages of 1765 ma for a Singhbhum 'newer dolerite' dyke swarm; Curr. Sci. 106 1306-1309.

Sen C and Dunn T 1995 Experimental modal metasomatism of a spinel lherzolite and the production of amphibole-bearing peridotite; Contrib. Mineral. Petrol. 119 422-432.

Sengupta P and Ray A 2012 Newer Dolerite dykes, Jharkhand, India: A case study of magma generation, differentiation and metasomatism in a subduction zone setting; Geochem. J. 46(6) 477-491.

Sengupta P, Ray A and Pramanik S 2014 Mineralogical and chemical characteristics of Newer Dolerite Dyke around Keonjhar, Orissa: Implication for hydrothermal activity in subduction zone setting; J. Earth Syst. Sci. 123(4) 887-904.

Shellnutt J G and MacRae N D 2012 Petrogenesis of the Mesoproterozoic (1.23 Ga) Sudbury dyke swarm and its questionable relationship to plate separation; Int. J. Earth Sci. (Geol. Rundsch) $1013-23$.

Singh M R, Manikyamba C, Ganguly S, Ray J, Santosh M, Singh D and Kumar C 2017 Paleoproterozoic arc basaltboninite-high magnesian andesite-Nb enriched basalt association from the Malangtoli volcanic suite, Singhbhum Craton, eastern India: Geochemical record for subduction initiation to arc maturation continuum; J. Asian Earth Sci. 134 191-206.

Srivastava R K, Ernst R, Hamilton M A and Bleeker W 2010 Precambrian large igneous provinces (LIPs) and their dyke swarms: New insights from high precision geochronology, paleomagnetism and geochemistry; Precamb. Res. 183(3) i-xi, 379-668.

Srivastava R K, Söderlund U, Ernstd R E, Mondal S K, Amiya K and Samala A K 2018 Precambrian mafic dyke swarms in the Singhbhum Craton (eastern India) and their links with dyke swarms of the eastern Dharwar Craton (southern India); Precamb. Res., https://doi.org/10.1016/j.precamres.2018.08. 001.

Sun S-S and McDonough W F 1989 Chemical and isotopic systematics of oceanic basalts: Implications for mantle composition and processes; Geol. Soc. London, Spec. Publ. 42 313-345.

Szilas K, Tusch J, Hoffmann J E, Garde A and Munker C 2016 Hafnium isotope constraints on the origin of Mesoarchaean andesites in southern West Greenland, North Atlantic Craton; In: Crust-mantle interactions and granitoid diversification: Insights from archaean cratons (eds) Halla J, 
Whitehouse M J, Ahmad T and Bagai Z, Geol. Soc. London, Spec. Publ. 449, http://doi.org/10.1144/SP449.2.

Thybo H and Artemieva I M 2013 Moho and magmatic underplating in continental lithosphere; Tectonophys. 609 605-619, https://doi.org/10.1016/j.tecto.2013.05.032.

Tommasini S, Avanzinelli R and Conticelli S 2011 The Th/La and $\mathrm{Sm} / \mathrm{La}$ conundrum of the Tethyan realm lamproites; Earth Planet. Sci. Lett. 301 469-478.

Upadhyaya D, Chattopadhyaya S, Kooijmanb E, Mezgerc K Jr and Berndtd J 2014 Magmatic and metamorphic history of Paleoarchean tonalite-trondhjemite-granodiorite (TTG) suite from the Singhbhum Craton, Eastern India; Precamb. Res. 252 180-190.

Volkert R A, Feigenson M D, Mana S and Bolge L 2015 Geochemical and $\mathrm{Sr}-\mathrm{Nd}$ isotopic constraints on the mantle source of Neoproterozoic mafic dikes of the rifted eastern Laurentian margin, north-central Appalachians, USA; Lithos 212 202-213.

Wang Y, Fan W, Zhang Y, Guo F, Zhang H and Peng T 2004 Geochemical, ${ }^{40} \mathrm{Ar} /{ }^{39} \mathrm{Ar}$ geochronological and $\mathrm{Sr}-\mathrm{Nd}$ isotopic constraints on the origin of Paleoproterozoic mafic dikes from the southern Taihang Mountains and implications for the ca.1800 Ma event of the North China Craton; Precamb. Res. $13555-77$.

Corresponding editor: N V Chalapathi RaO
Weaver B L and Tarney J 1981 The Scourie dyke suite: petrogenesis and geochemical nature of the Proterozoic sub-continental mantle; Contrib. Mineral. Petrol. 78 $175-188$.

Weaver B L and Tarney J 1984 Empirical approach to estimating the composition of the continental crust; Nature $310575-577$.

Wilson M 1989 Igneous petrogenesis - A global tectonic approach; Harper Collins, London, 466p.

Wood D A 1980 The application of a Th-Hf-Ta to problems of tectonomagmatic classification and to establishing the nature of crustal contamination of basaltic lavas of the British Tertiary volcanic province; Earth Planet. Sci. Lett. 50 11-30.

Yaxley G M, Crawford A J and Green D H 1991 Evidence for carbonatite metasomatism in spinel peridotites from western Victoria, Australia; Earth Planet. Sci. Lett. 197 $305-317$.

Zhao J H and Zhou M F 2007 Geochemistry of Neoproterozoic mafic intrusions in the Panzhihua district (Sichuan Province, SW China): Implications for subduction-related metasomatism in the upper mantle; Precamb. Res. 152 27-47. 